\title{
WestVirginiaUniversity
}

THE RESEARCH REPOSITORY @ WVU

Graduate Theses, Dissertations, and Problem Reports

2004

\section{Three essays on transfers, trade policy and welfare}

Jonathan Munemo

West Virginia University

Follow this and additional works at: https://researchrepository.wvu.edu/etd

\section{Recommended Citation}

Munemo, Jonathan, "Three essays on transfers, trade policy and welfare" (2004). Graduate Theses, Dissertations, and Problem Reports. 2088.

https://researchrepository.wvu.edu/etd/2088

This Dissertation is protected by copyright and/or related rights. It has been brought to you by the The Research Repository @ WVU with permission from the rights-holder(s). You are free to use this Dissertation in any way that is permitted by the copyright and related rights legislation that applies to your use. For other uses you must obtain permission from the rights-holder(s) directly, unless additional rights are indicated by a Creative Commons license in the record and/ or on the work itself. This Dissertation has been accepted for inclusion in WVU Graduate Theses, Dissertations, and Problem Reports collection by an authorized administrator of The Research Repository @ WVU.

For more information, please contact researchrepository@mail.wvu.edu. 
Three Essays on Transfers, Trade Policy and Welfare

$$
\text { Jonathan Munemo }
$$

\author{
Dissertation submitted to the \\ College of Business and Economics \\ at West Virginia University \\ in partial fulfillment of the requirements \\ for the degree of \\ Doctor of Philosophy
in \\ Economics
}

\begin{abstract}
Subhayu Bandyopadhyay, Ph.D., Chair Ashok B. Abbott, Ph.D.

Ronald J. Balvers, Ph.D.

Sudeshna C. Bandyopadhyay, Ph.D.

Stratford M. Douglas, Ph.D.

Division of Economics and Finance

Morgantown, West Virginia

2004
\end{abstract}

Key words: transfers, trade policy, welfare

(c) Copyright by Jonathan Munemo, 2004 


\section{Abstract \\ Three Essays on Transfers, Trade Policy and Welfare}

\section{Jonathan Munemo}

The objective of this dissertation is to incorporate structural factors in the analysis of welfare and trade policies of developing countries. The first chapter gives an introduction to this study. Chapter two provides an analysis of the welfare effect of financial transfers and capital transfers in the presence of trade taxes. We build a twogood general equilibrium model, which takes into account the use of foreign capital in the import competing sector and the use of land in the exporting sector by developing countries. Labor is used in both sectors. Financial transfers induce changes in commodity terms of trade, which in turn affects capital inflows and the price of imported capital. The welfare effect of financial transfers is considered in the context of induced changes in these variables. In the context of an exogenous export tax, we find that endogenous capital flows aggravate the transfer problem that exists under trade taxation. When trade liberalization is tied to financial aid, we find that the tying of aid may worsen or alleviate the transfer problem, depending on how the existing export tax compares with the optimum. In the case of capital transfers, we find that such transfers can reduce welfare through an adverse price effect and a production distortion.

In chapter three, we build an econometric model and empirically analyze the transfer problem in the presence of an exogenous export tax and endogenous capital inflows. This is done by estimating a regression model with fixed effects for a panel of 14 countries in Sub-Saharan Africa (SSA). Our empirical results show that multilateral transfers significantly reduce terms of trade. The reduction in terms of trade significantly induces foreign capital inflows. Increased capital inflows and terms of trade deterioration significantly offset the real GDP gains from multilateral transfers. The results are found to be robust. Chapter four analyzes how trade liberalization affects labor under-utilization (underemployment) and welfare. We show that liberalizing trade by reducing export taxes has an ambiguous effect on the welfare of a small open economy due to the presence of endogenous underemployment. In fact, free trade is not optimal: we find that a small export tax leads to a welfare improvement. Our results also show that the 
structure of employment in a typical small open economy causes trade liberalization to increase rather than decrease the level of underemployment. We check to see whether this latter result holds empirically by estimating a regression model with fixed effects for a panel of 19 developing economies. The empirical analysis shows that the result holds and is robust. In chapter five, we summarize the main conclusions of the dissertation and discuss future research. 


\section{Acknowledgements}

First of all, I would like to thank my advisor, Prof. Subhayu Bandyopadhyay for his guidance and invaluable support throughout this study. I have learnt a lot from his expertise in the field of international trade. Special thanks go to Prof. Balvers for providing me with many useful comments as well as suggestions, and for the stimulating discussions we had. I am indebted to Prof. Douglas, Prof. Sudeshna Bandyopadhyay, and Prof. Egorov for their assistance with econometrics. My thanks also go to Prof. Abbott for his advice on both the theoretical and empirical areas of my research. Many thanks to Prof. Trumbull for funding my conference trips with funds from the Economics Department. The feedback from participants at the various conferences was extremely helpful. Last but not least, my undying gratitude goes to Tanya for her sacrifice and support throughout my hectic research schedule. The standard disclaimer applies. 
To my mom who never stopped believing in me. 


\section{Table of Contents}

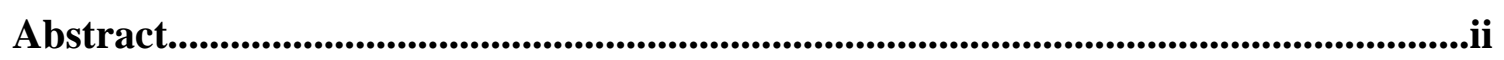

Acknowledgements.................................................................iv

List of Tables............................................................................viii

1. Introduction, Review of Literature and Overview of the Dissertation..........1

1.1. Introduction.......................................................

1.2. Review of related Literature.....................................

1.2.1. Transfers and welfare .......................................8

2.2.2. Trade policy and welfare ....................................11

1.3. Overview of the dissertation...................................... 13

2. Transfers, Trade Taxes and Endogenous Capital Flows.....................17

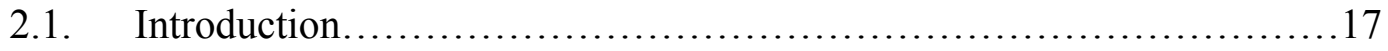

2.2. The model: financial transfers, taxes and endogenous capital Flows......24

2.2.1. The transfer problem in the presence of an exogenous export tax and endogenous capital inflows.................................28

2.2.2. The transfer problem in the context of trade liberalization tied to transfers....................................................... 30

2.3. Model Simulations............................................... 30

2.3.1. Functional forms......................................... 31

2.3.2. Solution and simulation results...........................32

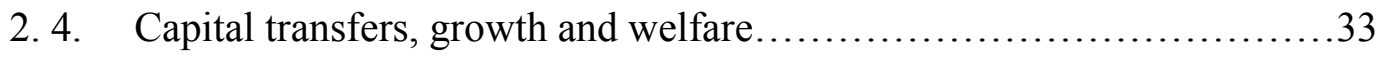

2.5. The model: capital transfers, taxes and welfare....................... 36

2.6. Summary and conclusions..................................40 
3. Transfers, Trade Taxes and Endogenous Capital Flows: An Empirical Analysis of Sub-Saharan Africa.............................................44

3.1. Introduction................................................. 44

3.1.1. Sub-Saharan's economic performance prior to reforms..........46

3.1.2. Sub-Saharan Africa's economic performance in the reform period..............................................48

3.1.3. Objectives..........................................54

3.2. Model specification and data description...........................55

3.3. Model estimation and results...................................58

3.4. Summary and conclusions....................................60

4. Trade Liberalization, Underemployment and Welfare: Is there a Conflict?.66

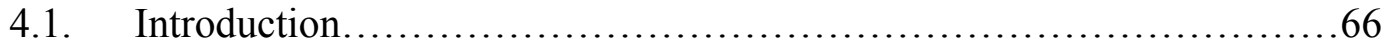

4.2. The model: export taxes, underemployment and welfare................74

4.3. Model specification and data description........................83

4.4. Model estimation and empirical results............................86

4.5. Summary and conclusions....................................87

5. Summary, Conclusions and Directions of Future Research..................90

5.1 Summary and conclusions of the dissertation....................... 90

5.2. Directions of future research...................................94

References.........................................................................96

Appendix I: Variables used and sources of data....................................102

Appendix II: Political Geography of Africa.......................................103

Appendix III: Multilateral Transfers to Sub-Saharan Africa......................104

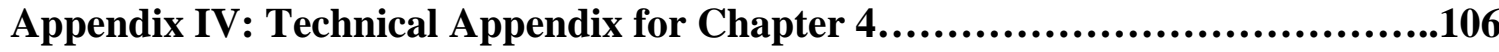




\section{List of Tables}

Table 2.1: Model solution.....................................................42

Table 2.2: Simulation results with tied aid...................................42

Table 2.3: Simulation results with untied aid....................................43

Table 3.1: Aid Per Capita (U.S. dollars) and GDP Per Capita Growth (\%) for Selected Countries in SSA, 1982-97..........................................62

Table 3.2: Equation (3.3) with two-way fixed effects...........................63

Table 3.3: Equation (3.2) with two-way fixed effects...........................63

Table 3.4: Equation (3.1) with two-way fixed effects...........................63

Table 3.2a: Equation (3.3a) with two-way fixed effects.........................64

Table 3.3a: Equation (3.2a) with two-way fixed effects........................64

Table 3.4a: Equation (3.1a) with two-way fixed effects..........................65

Table 4.1: Estimation results............................................. 89

Table 4.2: Estimation results with additional exogenous variables..................89 


\section{CHAPTER 1}

\section{Introduction, Review of Literature and Overview of the Dissertation}

\subsection{Introduction}

A number of developing countries are recipients of multilateral transfers. The term "multilateral transfers" refers to loans and credits from the International Monetary Fund and the World Bank. These transfers are an important source of income and thus welfare, given that most recipients are very poor in terms of per capita income. Most of the developing countries receiving international transfers have also embarked on trade liberalization. Liberalization of trade is the key component of a wider package of policy reforms. A study by Thomas (1989) shows that the vast majority of World Bank loans require a country to have a trade liberalization component in order to receive the loans. The overriding objective of policy reforms is to achieve sustained growth in per capita income that would translate into welfare gains (Corbo and Fischer, 1995). Multilateral transfers provide the bulk of income required for financing the policy reforms. ${ }^{1}$

Multilateral transfers to developing countries have traditionally been measured on the basis of the OECD's Official Development Assistance (ODA). ODA is made up of official financial flows in the form of grants and highly concessional loans. A loan is considered to be highly concessional if it has a grant element of at least 25 percent. Transfers are then measured by the net ODA, which is the net amount actually disbursed. Net ODA is however not very useful for analyzing the welfare effect of transfers. This is

\footnotetext{
${ }^{1}$ External finance is important because many developing countries are too poor to meet the financing requirements of policy reforms (see for example Helleiner, 1992). Other external resource flows into developing countries include bilateral lending, foreign direct investment, portfolio equity flows, bond issues, commercial bank lending and other private lending.
} 
because net ODA includes both grants and concessional loans. Such an aggregation overestimates the true aid content of loans. Only grants should be used to measure the aid content of loans because they represent pure unrequited transfers. Loans have to be repaid and therefore should not be considered to be part of a nation's income. An alternative approach to measuring aid flows is to use the World Bank (1998)'s Effective Development Assistance (EDA) data. EDA is an aggregate measure of aid flows combining total grants and the grant equivalents of all official loans. It thus captures the pure transfers from donors to recipients. Using EDA is therefore more useful for analyzing the welfare impact of multilateral transfers.

Multilateral transfers are financed by donor governments of rich nations. These donor governments have their own programs for delivering bilateral transfers. Bilateral transfers refer to loans and credits from governments including grants. Why is it that donor nations disburse some of their transfers through multilateral agencies rather than through their own bilateral programs? Rodrik (1995) suggests that information gathering and monitoring as well as conditionality provide the rationale for multilateral lending.

The level of bilateral as well as private transfers to developing countries is influenced by many factors. A crucial factor is the nature of government macro and micro economic policies in the developing countries. These transfers tend to be deterred from countries with risky policy environments. However, gathering information about policies as well as monitoring these policies is best performed by multilateral agencies. Such information is a public good in the sense that once available, it benefits everybody. As a result, individual donors have no incentive to gather this kind of information. Multilateral institutions do not face this incentive problem. 
In addition, multilateral agencies are better able to conduct policy monitoring since they are able to internalize informational externalities.

However, one can argue that the informational role of multilateral institutions by itself is not enough to justify multilateral lending. This role could have been easily performed without any lending involved. Rodrik (1995) notes that in the absence of multilateral lending, there is no incentive for these agencies to perform their information gathering and monitoring functions effectively. The reason is that if the agencies' own money is not at stake, chances are that they may be influenced by political and personal factors. As such, multilateral lending acts as an incentive for reliable information gathering and policy monitoring.

Conditionality refers to lending that is tied to changes in government policies. Rodrik (1995) notes that conditionality in lending is necessary to deal with the timeinconsistency problem. If there is no conditionality, developing countries can promise to undertake policy changes ex ante (before receiving the transfers) and then not pursue these policy changes ex post (after receiving the transfers). A follow-up question is why this conditionality role is not performed by the donor nations themselves. Rodrik (1995) suggests that multilateral conditionality is politically more acceptable than conditionality from rich industrial countries. The reason is that multilateral institutions are perceived as being autonomous from the political influence of industrial nations.

An analysis of the distribution of multilateral transfers and bilateral transfers supports the view that the former is less driven by political factors than the latter. Rodrik (1995) shows that the distribution of bilateral transfers is heavily concentrated in regions of political or strategic interest to the donor nation. For example, US transfers are found 
to be concentrated in the Middle East, Japan's transfers on east and southeast Asia and European Union transfers on Sub-Saharan Africa (SSA). Rodrik (1995) finds no evidence of such regional biases in multilateral transfers. Note however that if there are no incentive problems, conditionality need not be accompanied by lending activities. Multilateral agencies could as well negotiate policy changes to be implemented, while lending is provided by bilateral donors. However, if the multilateral agencies' resources are not at stake, there is no incentive for these agencies to enforce the desired policy changes. Therefore putting their own resources at stake ensures that multilateral agencies take policy conditionality seriously.

The rational for multilateral transfers can also be understood by analyzing what determines the transfers made by multilateral agencies to developing countries. Frey and Schneider (1986) provide four competing models of international lending activity. These are the needs model, the deserts model, the benevolence model, and the political economy model.

According to the needs model, multilateral agencies give transfers to countries which need them most. This view is certainly consistent with the period after 1970, when most transfers were given to poor countries. Based on the needs model, we would expect that transfers will be much higher in countries with low income per capita, high rates of inflation and high external debt. Therefore healthy indicators such as balance of payments surpluses and budget surpluses would imply that there is no need to offer large transfers.

The deserts model posits that transfers are given to countries which deserve them most. Nations are deemed deserving of transfers if they have potential for development 
and are creditworthy. Therefore sound economic and financial policies are rewarded with higher transfers. Indicators of creditworthiness include low inflation, a budget surplus, balance of payments surplus and low external debt. Low inflation indicates that a government has financially responsible policies. A surplus in the government budget shows that the government has savings. Balance of payments surpluses indicate a successful export policy while a low external debt indicates that a country can develop using internal resources. Good performance in the past also implies higher transfers because it proves that a country has the capability to do well in the future. In addition, a sound policy also implies that a country maintains political stability.

The benevolence model takes the view that officials of multilateral agencies are benevolent in the sense that their objective is to fulfill the agencies' goals. Some of these goals include promotion of economic growth and promotion of international trade. It follows therefore that countries with low per capita incomes are expected to receive more transfers. In addition, more open regimes are expected to receive higher transfers.

The political economy model regards multilateral institutions as bureaucracies in which the top officials maximize their individual utility subject to economic and political constraints. Top officials derive their utility from their prestigious positions and lending power. Prestige comes from the agencies' ability to perform an excellent job in their lending activities. This implies that the allocation of transfers to countries is expected to be influence by development needs as well as development potential. Power comes from the ability of top officials to use their discretion in granting transfers. Political constraints are caused by the interference of donor nations in the lending activities of multilateral institutions. Such interference can arise when donors use their voting power 
to influence the lending activities of multilateral agencies. Financial constraints arise because of the dependency on funds from donors. This means that the agencies will sometime yield to pressure from donors for the sake of securing future funding. Frey and Schneider (1986) test each of these models econometrically. They find that the political economy model best explains the lending behavior of the World Bank.

A substantial amount of foreign transfers to developing countries has taken place over the years. Sub-Saharan Africa (SSA) for example has been receiving these transfers since the onset of reforms in the early 1980s. Levy (1987) notes that SSA absorbs a large share of total ODA disbursements, which amounted to about one third in 1983 alone. Helleiner (1994) finds that in the early 1990s, SSA received $35 \%$ of total ODA to developing countries, compared to less than $10 \%$ in 1960 . The outcome of the transfers as well as the reforms in terms of progress towards restoring growth in per capita income is however disappointing. Africa remains the poorest continent in the world. Transfers and reforms have simply not delivered the expected welfare outcomes. The same dismal welfare result has been experienced in many other developing countries that have received multilateral transfers, as shown by Easterly (2003).

In the literature, several explanations have been offered to account for the poor performance of developing countries. The explanations include policy mistakes, exogenous factors and foreign transfers themselves. However, when analyzing the welfare of developing nations, we have to recognize that national welfare is also affected by structural factors. The literature in this area has not focused on how transfers and trade policy interact with structural factors to deliver welfare outcomes. A very important structural factor that needs to be factored into the welfare analysis is that most developing 
countries are highly dependent on imports of capital goods for production and investment. Evidence of this high import dependency can be found in Moran (1989). Imports of capital goods are financed using export earnings. Transfers affect the terms of trade and hence export earnings. They can also affect the price of capital goods. The effect on export earnings and price of capital determines the ability to import capital goods and therefore a nation's welfare.

The success of trade policy reforms in raising welfare and improving resource utilization does not depend on creating liberal trade regimes alone. There are some structural factors that need to be considered as well. A crucial structural factor is that underemployment or labor-underutilization is very high in developing countries. ${ }^{2}$ This implies that low unemployment rates can give a misleading picture about labor utilization. What really matters from a welfare point of view is how trade policy affects underemployment. The objective of this dissertation is to incorporate these structural factors in the analysis of welfare and trade policies of developing countries.

The rest of this chapter is organized as follows. Section 1.2 presents a review of existing literature on the welfare effects of transfers and trade policy. In section 1.3, we present an overview of the dissertation and outline the major results presented in this dissertation.

\subsection{Review of related Literature}

The review of literature is divided into two parts. In the first part, we review the theoretical and empirical literature on transfers and welfare. In the second part, we

\footnotetext{
${ }^{2}$ See for example ILO-KILM (2002).
} 
review the theoretical and empirical literature on trade policy and welfare. We also discuss how this dissertation seeks to contribute to the existing literature.

\subsubsection{Transfers and welfare}

In the literature, there is a distinction between aid that is tied and untied aid. Aid is said to be "tied" if its provision is made conditional on the recipient meeting conditions imposed by the donor. Untied aid is aid that is given with no conditionality attached. The welfare effect of aid is often analyzed using duality models. The income gains from the transfers are clearly welfare enhancing. However, transfers can also result in a price effect which reduces welfare. The price effect depends on the marginal propensity to consume the recipient's exports in both the donor and recipient nations. The theory of transfers and welfare shows that if the marginal propensity to consume is identical in both nations, the price effect is zero and positive income gains accrue to the recipient nation. If the recipient's marginal propensity to consume its exports is less than the donor's marginal propensity to consume these exports, then the aid induces a shift in the terms of trade against the recipient and in favor of the donor. This is the price effect of a transfer. The unfavorable shift in the terms of trade hurt the recipient's welfare. ${ }^{3}$

In the case of untied aid, Samuelson (1947) showed that in a two-country model, the recipient nation is assured of a net welfare gain only if its markets are competitive, stable and undistorted. Gale (1974) however showed that in the presence of bystanders (non-participating countries in the transfer), the price effect can dominate the income effect to cause a net reduction in the welfare of the recipient nation. This rather

\footnotetext{
${ }^{3}$ It should be noted that the negative shift in the terms of trade is highly possible in practice. This is because many developing countries produce primary products which are mostly consumed abroad.
} 
paradoxical outcome is referred to as "the transfer problem" (Eaton, 1989; Jones and Neary, 1984). Using the same model as Samuelson (1947), Kemp (1995) showed that the tying of aid may also result in a transfer paradox even if markets are stable, undistorted and competitive.

Gale (1974) and Kemp (1995)'s results are relevant for analyzing the effect of multilateral transfers on the welfare of developing countries. The fact that not every developing country receives a transfer gives rise to bystanders and as a result, transfer paradoxes cannot be ruled out. In addition, multilateral transfers to developing countries have policy-based conditionality as observed by Helleiner (1992) and Rodrik (1995). Some of the policies used for tying the transfers include stabilization policies (devaluation and complementary monetary and fiscal policies), institutional reform and market liberalization.

The empirical effect of foreign aid on the wellbeing of developing nations has been the subject of much debate since the 1960s. During the 1960s, 1970s and 1980s, empirical analysis was limited by data availability and the specification of an appropriate model was a debatable issue. A survey of this earlier literature can be found in Hansen and Tarp (2000). Burnside and Dollar (2000) find that aid has a positive effect on per capita growth in developing countries with good policies but has little effect in a bad policy environment.

Many papers have built on the work of Burnside and Dollar (2000). These papers include Hansen and Tarp (2001), Dalgaard and Hansen (2001), Guillamont and Chauvet (2001), Collier and Dehn (2001), Lensink and White (2001) and Collier and Dollar (2002). They introduce variations such as other exogenous variables, non-linear 
dependencies and interaction terms. Some of the findings from these papers are consistent with the Burnside and Dollar (2000) result, while some of them are not. Easterly (2003) finds that the Burnside and Dollar (2000) result is not robust to sample selection and alternative definitions of policies.

Africa in particular has generated a lot of research interest because it has been a major recipient of transfers since the early 1980s, but is still the poorest continent in the world. To be sure, there are many factors that could have contributed to the poor performance of Africa. Fischer and Corbo (1995) and Helleiner (1994) suggest problems related to policy design, poor sequencing of reforms, speed of reforms, reform credibility and weak institutions. Exogenous shocks such as unfavorable terms of trade, an increase in interest rates on foreign debt, and civil strife have also contributed to the weak performance (Wheeler, 1984).

Based on available cross-national data for the whole world, Easterly and Levine (1997) explain why per capita income has remained much lower in SSA compared to the rest of the world. The reasons are low schooling, political instability, underdeveloped financial systems, distorted foreign exchange markets, high government deficits and poor infrastructure. Sachs and Warner $(1995,1997)$ also use a global data set, but reach a different conclusion. They argue that trade policies, geography and demography explain why per capita income in SSA has remained low at a time when the rest of the world is enjoying much higher per capita incomes. The combination of closed trade policies, a tropical climate (characterized by poor health, poor soils and unreliable rainfall patterns), many landlocked countries and high population growth is seen to have adversely affected the wellbeing of SSA. 
Rodrik (1998) has analyzed variation in per capita income within SSA. According to his findings, the most important factors accounting for differentials in per capita income are: human resources (life expectancy), macro/fiscal policy (public savings), demography (changes in the dependency ratio), export policies (export taxes) and a catch-up/convergence factor (initial per-capita income). Collier and Gunning (1999), the IMF (1996) and the World Bank $(1981,1994)$ see policy misdirection as the main obstacle to welfare improvement. They therefore emphasize the need for policy reform.

As mentioned earlier, economies in developing countries reflect a structural dependence on imported capital goods. Growth therefore depends on these imports. Sustained economic growth in developing countries is expected to translate into welfare gains. This implies that the welfare of developing countries is affected by imports of capital goods. The above literature has not considered capital goods imports in the analysis of the transfer problem. This dissertation seeks to contribute to the literature by analyzing the transfer problem in the context of foreign capital goods.

\subsubsection{Trade policy and welfare}

Trade policy reform in developing countries aims to improve welfare by reducing production and consumption distortions and by expanding labor intensive employment. The trade regimes in developing economies are characterized by trade barriers such as import tariffs, export taxes and border delays. Greenaway and Milner (1991) observe that trade barriers are used to protect domestic industries from external competition as well as to raise revenue. However, these trade barriers reduce welfare by distorting production and consumption of tradable goods. High export taxes lead to under-production of export 
goods, while import tariffs and non-tariff barriers favor over-production of importcompeting goods. In addition, consumption is distorted because consumers pay a higher price for domestic goods which would be cheaper to import in the absence of tariff and non-tariff barriers. Reforming trade regimes by reducing trade barriers is expected to reduce these distortions and thereby improve welfare.

A typical developing economy is characterized by a labor intensive export sector and a capital intensive import-competing sector. The real product wage in the export sector is expected to fall relative to the real product wage in the import-competing sector following the liberalization of trade by reducing trade taxes. As a result, the export sector will expand relative to the import-competing sector. These changes will benefit the economy by increasing employment of labor.

The empirical literature has focused on how trade liberalization affects employment or unemployment. Some studies find that trade liberalization causes transitional unemployment as labor is reallocated out of the importables sector to the exportables sector. Other studies find that trade liberalization has little effect on employment or unemployment. Edwards (1993), provides a survey of this literature. To the best of our knowledge, the effect of trade liberalization on underemployment has not been investigated.

The employment gains from trade liberalization are achieved under the assumption that real wages are flexible and labor is homogeneous and inter-sectorally mobile. In reality, labor is not homogeneous. In many developing countries, the export sector is intensive in the use of unskilled labor and the import-competing sector is intensive in the use of skilled labor. Also, real wages are not fully flexible. Real wage 
rigidity results in underemployment or labor-underutilization. The ILO (2002) notes that underemployment is a problem that affects the majority of the population in developing countries. The welfare effect of trade liberalization will therefore largely depend on how underemployment is affected. This dissertation analyzes how trade liberalization affects underemployment and welfare.

\subsection{Overview of the dissertation}

This dissertation conducts a general equilibrium analysis of the welfare effects of transfers and trade policy. Three theoretical models are developed. The first model considers the welfare effect of financial transfers in the presence of trade taxes and capital flows. Our second model considers the effect of capital transfers on welfare. Based on the theoretical analysis, we derive an empirical model which relates welfare to transfers, trade taxes and capital flows. The empirical model is estimated using data on SSA. Our third theoretical model looks at trade liberalization, underemployment and welfare. The model is empirically estimated using data from a group of developing countries. The remainder of this dissertation is structured as follows. Chapters 2,3 , and 4 present the theoretical and empirical analysis. Chapter 5 provides a summary and conclusion of the dissertation as well as areas of future research interest. Below, is a brief description of the contents of each chapter.

Chapter two builds a two-nation, two-good general equilibrium model. The two nations are $\mathrm{A}$ and $\mathrm{B}$. $\mathrm{A}$ is a developing nation which produces goods 1 and 2 , and $\mathrm{B}$ is a developed nation which also produces goods 1 and 2 . Good-1 is a primary commodity (like cocoa) and is produced using labor and land. Good-2 is a manufactured good 
produced using labor and capital. Nation A exports good-1 to nation B and imports good-2 from it. Also, A uses foreign capital from B in the import competing sector (i.e., good-2). Nation A employs export taxes, while nation B follows free trade. The model is used to consider the welfare effect of financial transfers and capital transfers.

This model is consistent with the structure of production and trade observed in developing and developed countries. Many developing countries produce and export primary commodities. As noted before, trade taxes and dependence on imported capital goods is an important feature of developing countries. Developed countries on the other hand have much lower trade barriers. The assumption of free trade for developed countries therefore makes sense. In addition, industrial countries import largely primary goods from developing countries and export mainly industrial products to the developing countries.

We already know from Brecher and Bhagwati (1982) that in the presence of trade taxes, transfers may be recipient immiserizing. Therefore, we can expect a transfer paradox to be possible in this case. We find that financial transfers induce changes in commodity terms of trade, which in turn affects capital inflows and the price of imported capital. The welfare effect of these transfers is considered in the context of induced changes in these variables. In the case of capital transfers, we find that such transfers are associated with changes in prices, production and income. The impact of these changes on welfare is analyzed.

In chapter three, we build an econometric model and empirically analyze the transfer problem in the presence of an exogenous export tax and endogenous capital inflows. The empirical analysis is based on SSA. As noted before, SSA has been 
receiving a large share of multilateral transfers since the early 1980s. Like other developing countries, SSA is highly dependent on imported capital goods that are used in the import competing industrialized sector. Ndulu (1994) underscores the importance of imports for investment and production in SSA. Based on Ndulu (1994), over 75\% of imports in SSA are production related.

The importance of imports in production is also reflected by the strong relationship between incomes and imports. Lopez and Thomas (1990), find that income elasticities are in excess of one for SSA. There is also a positive and significant relationship between increased imports and growth as shown by Lopez and Thomas (1990), and Ndulu (1991). In addition Thomas and Lopez (1990) find that Africa's import-gdp ratio is around 25\%. The importance of capital goods imports cannot therefore be overemphasized. Our empirical model is derived from the general equilibrium model discussed in chapter 2 . We estimate a regression model with fixed effects for a panel of 14 countries in SSA. The estimation results are consistent with the theoretical analysis in chapter 2 and are robust.

Chapter four analyzes how trade liberalization affects underemployment and welfare in a small open economy. We present a general equilibrium trade model that explicitly takes into account the employment structure and wage inflexibility of a typical small open economy. The model has two sectors; a labor-intensive export sector and a capital-intensive import- competing sector. Real wages are assumed to be flexible in the export sector and rigid in the import-competing sector. The export sector uses unskilled labor and the import-competing sector uses skilled labor. Real wage rigidity in the skilled sector results in underemployment. 
This model of a small open economy can be applied to developing countries as observed by Knight (1976). Such a model can accurately assess the impact of trade liberalization on underemployment and welfare in a situation where labor is heterogeneous and real wage rigidity exists in some markets. If these structural factors are ignored, we are only able to assess the effect of trade liberalization on employment. As discussed before, such an assessment can give misleading information about labor utilization and welfare, given that there is high underemployment in developing countries.

Based on the general equilibrium model of a small open economy, we specify an empirical model for analyzing the effect of trade liberalization on underemployment. The model is also used to estimate the effects of changes in labor productivity, capital stock, and terms of trade on underemployment. We estimate the model using panel data for a group of developing countries for which data is available. The empirical effect of trade liberalization on underemployment is consistent with the theoretical analysis and is robust.

This dissertation is therefore an attempt at modeling the effect of transfers and trade policy on the welfare of developing countries using a general equilibrium framework. A theoretical as well as an empirical approach is used in the analysis. The focus of the research is on developing economies. The importance of structural factors in such an analysis is underscored. We accordingly take into account structural factors in our analysis. The concluding chapter explores the different ways in which we plan to extend this research. 


\section{CHAPTER 2}

\section{Transfers, Trade Taxes and Endogenous Capital Flows}

\subsection{Introduction}

Before Bretton Woods, transfers in the form of multilateral lending were uncommon. However after 1945, multilateral lending became a common practice. It was generally believed that private capital markets could not adequately provide the resources needed for post war reconstruction. The experience of the inter war period had shown that private capital flows had destabilizing effects and that there were inadequate capital markets to meet different financing requirements.

Following the completion of post war reconstruction, multilateral agencies now play an important role in shaping the economies of developing countries. Multilateral transfers are an important source of income in many poor developing countries. These transfers also provide the bulk of resources need to finance economic reforms that are being undertaken by several developing nations. The objective of these reforms is to create sustainable growth that would translate into welfare gains and thereby reduce poverty in the developing world.

Although multilateral agencies have disbursed significant amounts of transfers in support of policy reforms, the general consensus in policy cycles is that the amounts transferred so far are insufficient. There have recently been renewed calls to increase the volume of multilateral transfers to developing countries. These calls emerged after Burnside and Dollar (2000) showed that transfers help countries with good economic policies. The push for more transfers was clearly reflected during the U.N. conference on

"Financing for Development" in Monterrey, Mexico (2002). The Economist Magazine 
(March 2002), recommended increased transfers on the basis of the Burnside and Dollar (2000) paper. The Financial Times (2002) made the same point:

“..aid can help...it should be concentrated on countries with good macroeconomic policy. Estimates by Mr. Dollar and Mr. Burnside suggest that 1 percent of gross domestic product in aid given to a poor but well-managed country can increase its growth rate by a sustained 0.5 percentage points."

James Wolfensohn (2002), president of the World Bank, was explicit in recommending larger transfers on the basis that policies had improved in poor countries and therefore there should be "roughly a doubling of current aid flows."

The US president, George W. Bush (2002) promised a $\$ 5$ billion increase in foreign aid based on the fact that money that is complemented by economic reforms is not wasted. Although the Burnside and Dollar (2000) view that transfers are effective in a good policy environment cannot be denied, it should be noted that good policies are not the only factor that is crucial for a transfer to improve welfare. An analysis of the theory of transfers and welfare clearly shows that there are more fundamental issues involved, as explained in what follows next.

The issue of whether or not international transfers can change the recipient's welfare was at the center of the debate between Keynes (1929) and Ohlin (1929) on German reparation payments after World War I. In principle, a transfer affects a recipient's welfare through an income effect and a price effect. The income effect represents the transfer of purchasing power and is clearly welfare enhancing. On the other hand, the price effect represents the induced change in the terms of trade. 
This price effect depends on the marginal propensity to consume the recipient's exports in both the donor and recipient nations. The theory of transfers and welfare shows that if the marginal propensity to consume is identical in both nations, the price effect is zero and positive income gains accrue to the recipient nation. If the recipient's marginal propensity to consume its exports is less than the donor's marginal propensity to consume these exports, then the aid induces a shift in the terms of trade against the recipient and in favor of the donor. Under these circumstances, the price effect opposes the income effect. On the other hand if the recipient's marginal propensity to consume its exports is more than the donor's marginal propensity to consume these exports, the resulting shift in the terms of trade reinforces the income effect.

The Keynes (1929) and Ohlin (1929) debate focused on whether international transfers would produce unfavorable price effects that would result in a net reduction of the recipient's welfare. Samuelson (1947) showed that in a competitive, two-good, twocountry, and distortion- free general equilibrium model that assumes market stability, the recipient gains and the donor loses from international transfers. Later contributions of Bhagwati, Brecher and Hatta (1983), Kemp and Kojima (1985), Schweingerger (1990), and Kemp (1995), among others, show that recipient impoverishment is possible if one departs from the context of Samuelson (1947).

Departures from Samuelson (1947) arise if there are distortions or bystanders, even in the presence of market stability. Gale (1974) extended Samuelson's model and considered three rather than two countries. Transfers take place between two countries and the third country is simply a bystander (a non-participant in the transfer arrangement). Gale (1974) showed that in this case, the price effect can dominate the 
income effect to cause a net reduction in the welfare of the recipient nation. This rather paradoxical outcome is referred to as "the transfer problem" (Eaton, 1989; Jones and Neary, 1984).

The intuition behind Gale (1974)'s result can be explained by looking at the price effect. Note that the change in the terms of trade is determined only by the difference in marginal propensity to consume between the recipient and donor. The bystander's marginal propensity to consume has no effect on the terms of trade. Therefore, the bystander can only gain or lose from any resulting changes in its terms of trade. The improvement in the donor's terms of trade can cause the bystander to react by raising its price of exportable goods. As a result, the recipient of the transfer will now suffer a terms of trade loss against both its trading partners. The price effect is therefore amplified and can result in a net welfare loss.

In other contributions, it has been shown that the existence of distortions such as trade taxes and non competitive prices can lead to a welfare paradox. Brecher and Bhagwati (1982), show that in the two-good, two country model analyzed by Samuelson (1947), production distortions due to trade taxes can cause transfers to immiserize the recipient, even if markets are stable. To see why this is possible, let us assume that the two goods under consideration are an import good and an export good. Suppose the recipient imposes a tariff on imports. The deterioration in the terms of trade of the recipient that accompanies a transfer from the other nation expands output of the importable good in the recipient country. However, we know that this good was already being overproduced as a result of the tariff. Thus the price effect compounds the existing 
overproduction. As a result of this induced production distortion, the recipient nation can suffer a net welfare loss.

Bhagwati, Brecher and Hatta (1983) analyze the effect of distortions in the two good, three nation model in which one of the nations is a bystander. They find that immerizing transfers cannot be ruled out even if stability conditions are satisfied. Transfers that are subject to conditionality are another cause of the transfer paradox. Using the same model as Samuelson (1947), Kemp (1995) showed that the tying of aid may result in a transfer paradox even if markets are stable, undistorted and competitive.

To see why tied transfers can be immiserizing for the recipient, let us assume that the transfer is given subject to the condition that the recipient must spend more on the donor's export good. If this conditionality causes the recipient to spend more on the donor's export than what the recipient would have spent in the absence of such conditionality, the price effect favors the donor. Therefore if the price effect outweighs the income effect, the recipient will experience a net welfare loss.

In Kemp (1995), the government's forced expenditure pattern is responsible for the welfare paradox. The analysis can be extended by adding a private sector to the model. It then follows that if the government's constrained expenditure pattern affects the private sector's expenditure pattern, a net welfare loss will occur for the recipient nation. In fact this outcome is discussed in Schweinberger (1990).

There are other forms of conditionality. For example, transfers can be tied to a specific project or policy. Helleiner (1992) points out that during the 1970s, the IMF provided low conditionality transfers to developing countries. Similarly, the World Bank also provided low conditionality transfers during this period in the form of project 
finance. However from the 1980s, both IMF and World Bank transfers became highly conditional. The conditions placed on transfers by the multilateral agencies included macroeconomic stability, price liberalization, privatization of loss making parastatals and open trade regimes.

A crucial structural factor that has not been explicitly considered by the literature in this area is that investment and production may be highly depended on imported capital goods such as machinery and transport equipment. When analyzing the welfare effects of transfers, we therefore have to recognize that for some countries, national welfare is also affected by imported capital goods. The objective of this chapter is to take into account capital goods imports in the welfare analysis of transfers. We build a twogood, two-nation general equilibrium model. Nation A is a developing country and Nation B is a developed country. The import-competing sector of nation A uses foreign capital from nation B. In addition, nation A receives transfers of financial resources or capital from nation B.

Foreign financial transfers induce changes in commodity terms of trade, which in turn affects capital inflows and the price of imported capital. Capital transfers are associated with changes in the terms of trade, production and income. The welfare effect of transfers is considered in the context of induced changes in these variables.

The export sector of nation A produces a primary commodity using labor and land. An export tax is in place. We already know from Brecher and Bhagwati (1982) that in the presence of trade taxes, transfers may be recipient immiserizing. Therefore, we can expect a transfer paradox to be possible in this case. We show that endogenous capital inflows induced by financial transfers may aggravate this transfer problem. When 
a transfer worsens the terms of trade, it expands the import competing sector. As in Brecher and Bhagwati (1982), this leads to a misallocation of resources by contracting trade further compared to the free trade outcome. ${ }^{4}$

In addition, expansion of the import competing sector raises the demand for capital and its rate of return. Thus, more is paid to foreign capital and this is a terms of trade loss in the factor market. In response to the higher return on capital, inflows occur, further expanding the import competing sector. Thus, both the value effect (higher price of imported capital) and the volume effect (greater inflow of capital) tend to reduce welfare. If the transfer is tied to liberalization of trade, then if the existing export tax is below its optimal level, an additional loss may be incurred.

We also show that changes in production and terms of trade that are caused by capital transfers can lead to immiserzing growth. The presence of a trade distortion can cause the price effect and production effect to overcome the income effect. As a result, the recipient suffers a net welfare loss. The recipient's welfare falls despite the fact that productive capacity and hence growth has been increased by the transfer of capital.

The theoretical model and theoretical analysis are presented in section 2.2. In section 2.3 , the model is solved numerically and used to simulate the effects of foreign aid on welfare. The focus in sections 2.2 and 2.3 is on financial transfers. In section 2.4, we discuss capital transfers, growth and welfare. The model of capital transfers, taxes and welfare is analyzed in section 2.5 . Section 2.6 presents the summary and conclusions.

\footnotetext{
${ }^{4}$ In our model, an export tax is used. However, by virtue of the Lerner symmetry theorem, the export tax has similar effects as an import tariff.
} 


\subsection{The model: financial transfers, taxes and endogenous capital flows}

Let there be two nations $\mathrm{A}$ and $\mathrm{B}$. A is a developing nation which produces two goods 1 and 2, and B is a developed nation which also produces goods 1 and 2. Both goods are produced using CRS technology. Good-1 is a primary commodity (like Cocoa) and is produced using labor and land. Good-2 is a manufactured good produced using labor and capital. Nation A exports good-1 to nation B and imports good-2 from it. Also, A imports physical capital from B for use in the import competing sector (i.e., good-2). Suppose B gives a transfer to A of an amount T. The effect of this transfer on the terms of trade and the welfare of $\mathrm{A}$ is considered below. The expenditure-revenue identities of the two nations are: ${ }^{5}$

$$
\begin{aligned}
& E^{A}\left(p(1-t), 1, U^{A}\right)=R^{A}\left\{p(1-t), 1, K^{A}+K^{I}\right\}+t p\left(R_{1}^{A}-E_{1}^{A}\right)+T-R_{3}^{A} K^{I} . \\
& \left(p, 1, U^{B}\right)=R^{B}\left(p, 1, K^{B}-K^{I}\right)-T+R_{3}^{A} K^{I} .
\end{aligned}
$$

Capital is imported by nation-A from nation-B till their value of marginal product is equalized:

$$
\mathrm{R}_{3}^{\mathrm{A}}\left\{\mathrm{p}(1-\mathrm{t}), 1, \mathrm{~K}^{\mathrm{A}}+\mathrm{K}^{\mathrm{I}}\right\}=\mathrm{R}_{3}^{\mathrm{B}}\left(\mathrm{p}, 1, \mathrm{~K}^{\mathrm{B}}-\mathrm{K}^{\mathrm{I}}\right) .
$$

The market clearing equation for good-1 is:

\footnotetext{
${ }^{5}$ We will use the convention that for any function $f(),. f_{i}($.$) is the partial derivative of the function with$ respect to the $i^{\text {th }}$ argument. Similarly, $f_{i j}($.$) is the partial derivative of the function f_{i}($.$) with respect to the j^{\text {th }}$ argument.
} 


$$
\mathrm{E}_{1}^{\mathrm{A}}\left(\mathrm{p}(1-\mathrm{t}), 1, \mathrm{U}^{\mathrm{A}}\right)+\mathrm{E}_{1}^{\mathrm{B}}\left(\mathrm{p}, 1, \mathrm{U}^{\mathrm{B}}\right)=\mathrm{R}_{1}^{\mathrm{A}}\left\{\mathrm{p}(1-\mathrm{t}), 1, \mathrm{~K}^{\mathrm{A}}+\mathrm{K}^{\mathrm{I}}\right\}+\mathrm{R}_{1}^{\mathrm{B}}\left(\mathrm{p}, 1, \mathrm{~K}^{\mathrm{B}}-\mathrm{K}^{\mathrm{I}}\right) .
$$

Equations (2.1) through (2.4) determine $\mathrm{U}^{\mathrm{A}}, \mathrm{U}^{\mathrm{B}}, \mathrm{p}$ and $\mathrm{K}^{\mathrm{I}}$ as functions of the export tax rate $t$ and the transfer level $T$. For simplicity, we solve the model recursively in the following manner. Relations (2.1), (2.2) and (2.3) implicitly define (2.1a), (2.2a) and (2.3a) below, respectively:

$$
\begin{aligned}
& \mathrm{U}^{\mathrm{A}}=\mathrm{U}^{\mathrm{A}}\left(\mathrm{p}, \mathrm{t}, \mathrm{K}^{\mathrm{I}}, \mathrm{T}\right) . \\
& \mathrm{U}^{\mathrm{B}}=\mathrm{U}^{\mathrm{B}}\left(\mathrm{p}, \mathrm{t}, \mathrm{K}^{\mathrm{I}}, \mathrm{T}\right) . \\
& \mathrm{K}^{\mathrm{I}}=\mathrm{K}^{\mathrm{I}}(\mathrm{p}, \mathrm{t}) .
\end{aligned}
$$

Using (2.1a), (2.2a) and (2.3a) in (2.4) we have:

$$
\begin{aligned}
& \mathrm{E}_{1}^{\mathrm{A}}\left\{\mathrm{p}(1-\mathrm{t}), 1, \mathrm{U}^{\mathrm{A}}(.)\right\}+\mathrm{E}_{1}^{\mathrm{B}}\left\{\mathrm{p}, 1, \mathrm{U}^{\mathrm{B}}(.)\right\} \\
& =\mathrm{R}_{1}^{\mathrm{A}}\left\{\mathrm{p}(1-\mathrm{t}), 1, \mathrm{~K}^{\mathrm{A}}+\mathrm{K}^{\mathrm{I}}(.)\right\}+\mathrm{R}_{1}^{\mathrm{B}}\left\{\mathrm{p}, 1, \mathrm{~K}^{\mathrm{B}}-\mathrm{K}^{\mathrm{I}}(.)\right\}
\end{aligned}
$$

Relation-(2.4a) defines:

$$
\mathrm{p}=\mathrm{p}(\mathrm{t}, \mathrm{T})
$$


From (2.4b) we obtain the terms of trade $\mathrm{p}$ as a function of the exogenous variables $t$ and $T$. Substituting for $p$ and using the value of $t$, we obtain $\mathrm{K}^{\mathrm{I}}$ from (2.3a). Finally, we can solve for $\mathrm{U}^{\mathrm{A}}$ and $\mathrm{U}^{\mathrm{B}}$ from (2.1a) and (2.2a), respectively.

We explore in some detail below the effect of different variables and parameters in this model on the welfare of nation-A. This will be useful for a better understanding of the analysis that will follow. Differentiating (2.1a) we have:

$$
\mathrm{dU}^{\mathrm{A}}=\mathrm{U}_{1}^{\mathrm{A}} \mathrm{dp}+\mathrm{U}_{2}^{\mathrm{A}} \mathrm{dt}+\mathrm{U}_{3}^{\mathrm{A}} \mathrm{dK}+\mathrm{U}_{4}^{\mathrm{A}} \mathrm{dT} .
$$

The first term on the right hand side of (2.1b) captures the terms of trade effect. In addition to the standard gains from commodity terms of trade, the rise in price of the export good leads to a reduction in the rate of return of capital in A, thereby reducing its payments on foreign capital. Thus, the standard terms of trade effect is complemented by an induced terms of trade effect on factor price of an imported input. To be precise:

$\mathrm{U}_{1}^{\mathrm{A}}=\left[\left(\mathrm{R}_{1}^{\mathrm{A}}-\mathrm{E}_{1}^{\mathrm{A}}\right)+\operatorname{tp}(1-\mathrm{t})\left(\mathrm{R}_{11}^{\mathrm{A}}-\mathrm{E}_{11}^{\mathrm{A}}\right)-\mathrm{K}^{\mathrm{I}} \mathrm{R}_{31}^{\mathrm{A}}(1-\mathrm{t})\right] / \mathrm{D}^{\mathrm{A}}>0 ; \mathrm{D}^{\mathrm{A}}=\mathrm{E}_{3}^{\mathrm{A}}+\operatorname{tpE}_{13}^{\mathrm{A}}>0$.

The first term on the right hand side of the first equation in (2.1c) is the gain from exporting the existing level of exports at a higher price. The second term measures the gains in tax revenue from the expansion of exports. The last term is the gains from 
reduced price of capital imports (noting that the effect of $\mathrm{p}$ on $\mathrm{R}_{3}^{\mathrm{A}}$ is negative). ${ }^{6}$ The direct effect of the tariff on $\mathrm{U}^{\mathrm{A}}$ (i.e., $\mathrm{U}_{2}^{\mathrm{A}}$ ) is negative:

$\mathrm{U}_{2}^{\mathrm{A}}=\mathrm{p}\left\{\mathrm{tp}\left(\mathrm{E}_{11}^{\mathrm{A}}-\mathrm{R}_{11}^{\mathrm{A}}\right)+\mathrm{K}^{\mathrm{I}} \mathrm{R}_{31}^{\mathrm{A}}\right\} / \mathrm{D}^{\mathrm{A}}<0$.

A rise in the export tax (for a given $\mathrm{p}$ ) causes the usual production and consumption distortions by reducing the domestic price of good-1 and also leads to a rise in the return to capital. The latter compounds the costs of the tariff by raising the payments on foreign capital. The direct effect of capital imports is measured by:

$\mathrm{U}_{3}^{\mathrm{A}}=\left(\operatorname{tpR}_{31}^{\mathrm{A}}-\mathrm{K}^{\mathrm{I}} \mathrm{R}_{33}^{\mathrm{A}}\right) / \mathrm{D}^{\mathrm{A}}$.

This effect has an ambiguous sign. A capital inflow will reduce the production of good1, aggravating the existing trade distortion. On the other hand, the fall in return on capital reduces the payment on foreign capital and is welfare enhancing. Finally, the direct effect of a transfer (for a given $\mathrm{p}, \mathrm{t}$ and $\mathrm{K}^{\mathrm{I}}$ ) is standard and is positive:

$\mathrm{U}_{4}^{\mathrm{A}}=1 / \mathrm{D}^{\mathrm{A}}$

Noting that $\mathrm{p}$ and $\mathrm{K}^{\mathrm{I}}$ are endogenous, we use $(2.1 \mathrm{~b}),(2.3 \mathrm{a})$ and $(2.4 \mathrm{~b})$ to obtain:

\footnotetext{
${ }^{6}$ Note that good-1 is made by labor and land and good-2 by labor and capital. A rise in the price of good-1 will expand that sector and contract sector-2. The demand for capital will fall and so will its rate of return.
} 


$$
\mathrm{dU}^{\mathrm{A}}=\left(\alpha \mathrm{p}_{1}+\beta\right) \mathrm{dt}+\left(\alpha \mathrm{p}_{2}+\mathrm{U}_{4}^{\mathrm{A}}\right) \mathrm{dT} \text {, where, } \alpha=\mathrm{U}_{1}^{\mathrm{A}}+\mathrm{U}_{3}^{\mathrm{A}} \mathrm{K}_{1}^{\mathrm{I}} \text {; and, } \beta=\mathrm{U}_{2}^{\mathrm{A}}+\mathrm{U}_{3}^{\mathrm{A}} \mathrm{K}_{2}^{\mathrm{I}} \text {. }
$$

\subsubsection{The transfer problem in the presence of an exogenous export tax and endogenous capital inflows}

Using the fact that $t$ is exogenous (for the current analysis) and using (2.5), we have:

$$
\mathrm{dU}^{\mathrm{A}} / \mathrm{dT}=\left(\mathrm{U}_{1}^{\mathrm{A}}+\mathrm{U}_{3}^{\mathrm{A}} \mathrm{K}_{1}^{\mathrm{I}}\right) \mathrm{p}_{2}+\mathrm{U}_{4}^{\mathrm{A}} .
$$

The first term on the right hand side of (2.6) reflects the terms of trade effect of the transfer. The change in terms of trade is:

$$
\mathrm{p}_{2}=\left\{\left(\mathrm{E}_{13}^{\mathrm{A}} / \mathrm{D}^{\mathrm{A}}\right)-\left(\mathrm{E}_{13}^{\mathrm{B}} / \mathrm{D}^{\mathrm{B}}\right)\right\} / \mathrm{MLC} ; \mathrm{D}^{\mathrm{B}}=\mathrm{E}_{3}^{\mathrm{B}}
$$

MLC is the slope of the global excess supply function and is positive to ensure stability.

We will assume that the marginal propensity to consume the primary commodity is higher in B compared to A. ${ }^{7}$ This ensures that the numerator of (2.7) is negative, and thus the terms of trade effect of the transfer is negative. Using (2.7) we can inspect (2.6) and find that the sign of the welfare effect is ambiguous. The standard two-country transfer problem has been compounded by two factors. First, an exogenous distortion in the form of an export tax is present. Second, capital flows occur in response to the terms

\footnotetext{
${ }^{7}$ This is fairly standard for primary product exporting nations. For example, cocoa producing nations consume very little cocoa and the market lies mostly in developed nations. The literature in this area often ignores the domestic consumption of the export good. In this case, the terms of trade effect in equation(2.7) is necessarily negative under normality in consumption.
} 
of trade change and this in turn affect welfare. To throw further light on this problem, we reduce (2.6) to:

$$
\mathrm{dU}^{\mathrm{A}} / \mathrm{dT}=\left[\left\{\left(\operatorname{Exp}_{1}^{\mathrm{A}}+\theta^{\mathrm{A}}\right) \mathrm{p}_{2}+1\right\} / \mathrm{D}^{\mathrm{A}}\right]+\left[\mathrm{U}_{3}^{\mathrm{A}} \mathrm{K}_{1}^{\mathrm{I}}-\left\{\mathrm{K}^{\mathrm{I}} \mathrm{R}_{31}^{\mathrm{A}}(1-\mathrm{t}) / \mathrm{D}^{\mathrm{A}}\right\}\right] \mathrm{p}_{2} .
$$

The first term on the right hand side of (2.8) is the standard welfare effect of a transfer in the presence of a fixed export tax. ${ }^{8}$ The second term is the effect of the endogenous capital flows. The second term can be shown to be strictly negative. Thus, endogenous capital flows aggravate the transfer problem that exists under trade taxation.

When A receives a transfer, its term of trade worsens (assuming $\mathrm{p}_{2}<0$ ). The fall in $\mathrm{p}$ expands sector-2. More capital is needed, leading to a rise in the return to capital (standard result in a specific factor context). Capital inflows occur, expanding the import competing sector. There are three effects in the context of endogenous capital flows that are worth explaining. ${ }^{9}$ First, the rise in the return to capital leads to a higher payment on capital imports and this leads to a welfare loss. Second, the induced inflow of capital reduces the return on capital and this leads to a rise in welfare. Finally, the inflow of capital expands the protected sector, and this aggravates the trade distortion. The first and the third effects dominate, and therefore the induced capital inflow is welfare reducing.

\footnotetext{
${ }^{8}$ Brecher and Bhagwati (1982) show that in the presence of import tariffs, transfers can be immiserizing if they lead to an expansion of the protected sector. In a related context, Bandyopadhyay and Majumdar (2003) explore the transfer problem in a three-country export taxation model and find a similar result.

${ }^{9}$ The explanation relies on the last term in (2.8), relation-(2.1e) and the expression for $\mathrm{K}_{1}^{\mathrm{I}}$ obtained from (2.3a).
} 


\subsubsection{The transfer problem in the context of trade liberalization tied to transfers} (i.e., $d t / d T<0)$.

Often donor nations or agencies tie the provision of aid to liberalization of trade. In our context, this implies that the export tax $t$ is negatively related to the transfer $T$. This sub-section briefly focuses on the transfer problem in that context. Using (2.5), we have:

$$
d U^{A} / d T=\left(\alpha p_{1}+\beta\right)(d t / d T)+\left(\alpha p_{2}+U_{4}^{A}\right) .
$$

The first term on the right hand side reflects the standard welfare effect of a trade tax. The term $\alpha p_{1}$ measures the terms of trade gain from a trade tax, while $\beta$ measures the efficiency loss from the trade tax. If the trade tax is optimally set, the term $\left(\alpha p_{1}+\beta\right)$ is zero, and the effects of the transfer are as explored in the previous section. However, if

the tax is too low (relative to the optimal), then $\left(\alpha p_{1}+\beta\right)$ is positive, and trade liberalization tied to transfers will aggravate the transfer problem. Therefore, depending on how the existing export tax compares with the optimum, the tying of aid may worsen or alleviate the transfer problem that we discuss in the previous sub-section.

\subsection{Model Simulations}

To shed more light on the transfer problem in the context of trade liberalization tied to transfers, we solve the model numerically and conduct simulations. We assume specific functional forms in order to perform the simulations. 


\subsubsection{Functional forms}

Let us assume Cobb-Douglas production functions for the two goods and a CobbDouglas utility function for nation A. Therefore we have:

$$
\begin{aligned}
& \mathrm{X}_{1}{ }^{\mathrm{A}}=\left(\mathrm{L}_{1}{ }^{\mathrm{A}}\right)^{\mathrm{a}}\left(\mathrm{K}_{1}{ }^{\mathrm{A}}\right)^{1-\mathrm{a}} \\
& \mathrm{X}_{1}^{\mathrm{B}}=\left(\mathrm{L}_{1}{ }^{\mathrm{B}}\right)^{\mathrm{d}}\left(\mathrm{K}_{1}{ }^{\mathrm{B}}\right)^{1-\mathrm{d}} \\
& \mathrm{X}_{\mathrm{N}}=\left(\mathrm{L}_{2}{ }^{\mathrm{A}}\right)^{\mathrm{b}}\left(\mathrm{K}_{2}{ }^{\mathrm{A}}\right)^{1-\mathrm{b}} \\
& \mathrm{U}^{\mathrm{A}}=\left(\mathrm{C}_{1}{ }^{\mathrm{A}}\right)^{\alpha}\left(\mathrm{C}_{\mathrm{N}}{ }^{\mathrm{A}}\right)^{1-\alpha} \\
& \mathrm{U}^{\mathrm{B}}=\left(\mathrm{C}_{1}{ }^{\mathrm{B}}\right)^{\vartheta}
\end{aligned}
$$

The assumed utility functions give rise to the following expenditure functions:

$E^{A}\left[P_{1}(1-t), 1, U^{A}\right]=(1-\alpha)^{\alpha-1} \alpha^{-\alpha}\left[P_{1}(1-t)\right]^{\alpha} U^{A}$

$\mathrm{E}^{\mathrm{B}}=\mathrm{P}_{1} \mathrm{C}_{1}{ }^{\mathrm{B}}$

Given the assumption of Cobb-Douglas production functions, we get the following revenue functions: 


$$
\begin{aligned}
& \mathrm{R}^{\mathrm{A}}\left[\mathrm{P}_{1}(1-\mathrm{t}), 1, \overline{\mathrm{L}}^{\mathrm{A}}, \overline{\mathrm{K}}^{\mathrm{A}}+\mathrm{K}_{\mathrm{I}}\right]=\overline{\mathrm{L}}^{\mathrm{A}} \mathrm{B}_{1}{ }^{\mathrm{s} 1} \mathrm{~B}_{2}{ }^{\mathrm{s} 2}\left[\mathrm{P}_{1}(1-\mathrm{t})\right]^{-\mathrm{s} 1}+\left(\overline{\mathrm{K}}^{\mathrm{A}}+\mathrm{K}_{\mathrm{I}}\right) \mathrm{B}_{1}{ }^{\mathrm{s} 3} \mathrm{~B}_{2}{ }^{\mathrm{s}}\left[\mathrm{P}_{1}(1-\mathrm{t})\right]^{\mathrm{s} 3} \\
& \mathrm{R}^{\mathrm{B}}\left(\mathrm{P}_{1}, \overline{\mathrm{K}}^{\mathrm{B}}-\mathrm{K}_{\mathrm{I}}\right)=\mathrm{P}_{1}\left(\overline{\mathrm{L}}^{\mathrm{B}}\right)^{\mathrm{d}}\left(\overline{\mathrm{K}}^{\mathrm{B}}-\mathrm{K}_{\mathrm{I}}\right)^{1-\mathrm{d}}
\end{aligned}
$$

where $\mathrm{s} 1=\frac{\mathrm{b}-1}{\mathrm{a}-\mathrm{b}} ; \mathrm{s} 2=\frac{1-\mathrm{a}}{\mathrm{a}-\mathrm{b}} ; \mathrm{s} 3=\frac{\mathrm{b}}{\mathrm{a}-\mathrm{b}} ; \mathrm{s} 4=-\frac{\mathrm{a}}{\mathrm{a}-\mathrm{b}}$

We assume the relation between tied aid and trade liberalization to be as follows:

$$
\mathrm{t}_{\mathrm{E}} \mathrm{T}=1
$$

\subsubsection{Solution and simulation results}

The functional forms allow us to solve the model to get explicit solutions and to carry out simulation exercises. We specify the following parameter configurations:

$\alpha=0.9, \vartheta=0.1, \overline{\mathrm{L}}^{\mathrm{A}}=3000, \overline{\mathrm{L}}^{\mathrm{B}}=1000, \overline{\mathrm{K}}^{\mathrm{A}}=500, \overline{\mathrm{K}}^{\mathrm{B}}=2000, \mathrm{a}=0.7, \mathrm{~d}=0.2, \mathrm{~b}=0.4$, $\mathrm{B} 1=0.4, \mathrm{~B} 2=3.0$ and $\mathrm{T}=10$.

Table 2.1 reports the results obtained when the model is solved using GAMS. The utility level of nation A is 792.1402 and the values for the other endogenous variables are also listed. $\mathrm{Q}^{\mathrm{A}}$ is quantity of good 1 supplied by nation $\mathrm{A}, \mathrm{D}^{\mathrm{A}}$ is quantity of good 1 demanded by nation $\mathrm{A}, \mathrm{r}^{\mathrm{A}}$ is the return to capital in nation $\mathrm{A}, \mathrm{r}^{\mathrm{B}}$ is the return to capital in nation $\mathrm{B}$, and $\mathrm{EX}_{1}{ }^{\mathrm{A}}$ is nation $\mathrm{A}$ 's exports.

We now simulate the effects of tied aid by considering the effects of a marginal increase in $\mathrm{T}$ from $\mathrm{T}=10$ to $\mathrm{T}=10.1$. Table 2.2 reports the simulation results. The 
results indicate that nation A suffers a utility loss following an increase in aid that is tied to trade liberalization. The utility level of nation A is now 792.0902. Terms of trade have declined as shown by the fall in the price of good 1 from 0.59292090 to 0.59249898. Since nation A has suffered a net welfare loss, we can conclude that the price effect dominates the income effect. As a result of the unfavorable terms of trade shift, exports respond weakly to the tax incentives, as suggested in table 2.2. The results also suggest that the non-traded sector benefits from tied aid through increased capital inflows. This further hurts the traded sector through a reallocation of labor.

In order to verify that tied aid is the cause of welfare loss in nation A, we considered the case of untied aid. We chose a parameter value for t equal to 0.1 in order to get the same results reported in table 2.1. We then proceeded to simulate the effects of untied aid by considering the effects of a marginal increase in $\mathrm{T}$ from $\mathrm{T}=10$ to $\mathrm{T}=10.1$. Table 2.3 reports the simulation results.

As suggested by theory, we see that when aid is untied, nation A benefits because the income effect dominates the price effect. Thus we have established that starting from the same level of utilities, untied aid increases the welfare of the recipient, while tied aid has a perverse welfare effect. We can therefore conclude that the tying of aid is responsible for the welfare loss in nation $\mathrm{A}$, given the functional forms and parameter values chosen.

\section{4. Capital transfers, growth and welfare}

So far we have discussed the transfer of financial resources. In this section we consider the transfer of foreign capital. As before, foreign capital expands the productive 
capacity of the import-competing sector. The import-competing sector will therefore produce more goods. It is interesting to find out how this induced economic growth from a capital transfer affects national welfare. This issue is important because it raises the possibility of immiserizing growth.

We will first illustrate immiserizing growth and then see if such immiserization can occur as a result of capital transfers. Let us modify the model on financial transfers, taxes and endogenous capital flows by dropping export taxes, financial transfers and capital flows. Using the same approach to solve the model, it can be shown that the terms of trade now depend on the capital endowment:

$$
\mathrm{p}=\mathrm{p}\left(\mathrm{K}^{\mathrm{A}}\right)
$$

The effect of the of the capital endowment on the terms of trade can be found by using the implicit function theorem on the market clearing equation for good 1 :

$$
\mathrm{dp} / \mathrm{dK}^{\mathrm{A}}=\left\{\left(\mathrm{R}_{1 \mathrm{~V}}{ }^{\mathrm{A}}-\mathrm{mpc} 1 \mathrm{R}_{\mathrm{V}}{ }^{\mathrm{A}}\right) / \mathrm{MLC}\right\} ; \mathrm{V}^{\mathrm{A}}=\mathrm{K}^{\mathrm{A}}
$$

MLC is the slope of the excess demand function and is negative to ensure stability. The term mpc1 is nation A's marginal propensity to consume good 1 . Suppose in this case, good 1 is the import good. Let us also assume that good 1 is labor intensive and good 2 is capital intensive (the export good). Suppose nation A experiences a growth in capital. From the Rybczynski theorem, we know that:

$$
\mathrm{R}_{1 \mathrm{~V}}{ }^{\mathrm{A}}<0
$$


The implication of (2.23) is that a rise in capital reduces the supply of good1 in nation A at given world prices. Therefore:

$\mathrm{dp} / \mathrm{dK}^{\mathrm{A}}\left\{\left(\mathrm{R}_{1 \mathrm{~V}}{ }^{\mathrm{A}}-\mathrm{mpc} 1 \mathrm{R}_{\mathrm{V}}{ }^{\mathrm{A}}\right) / \mathrm{MLC}\right\}>0$

Using the implicit function theorem on the budget constraint for nation $\mathrm{A}$, we can find the effect of a change in the capital endowment of nation $\mathrm{A}$ on the welfare of nation A:

$\mathrm{E}_{\mathrm{U}}{ }^{\mathrm{A}} \mathrm{dU}{ }^{\mathrm{A}} / \mathrm{dV}{ }^{\mathrm{A}}=-\mathrm{M} 1 / \mathrm{MLC}\left[\mathrm{R}_{1 \mathrm{~V}}{ }^{\mathrm{A}}+\mathrm{R}_{\mathrm{V}}{ }^{\mathrm{A}}(\mathrm{n} 1+\mathrm{n} 2-1) / \mathrm{p}\right]$

where:

$\mathrm{M} 1=\mathrm{R}_{1}{ }^{\mathrm{A}}-\mathrm{E}_{1}{ }^{\mathrm{A}}<0$

The expression (2.24) contains the compensated excess supply elasticity which is given by $\mathrm{n} 1$ and is positive. In (2.24), we also have the foreign import demand, which is given by $\mathrm{n} 2$. Therefore if foreign import demand is inelastic $(\mathrm{n} 2<1)$, we have:

$\mathrm{dU}^{\mathrm{A}} / \mathrm{dV}^{\mathrm{A}} \leq 0$

From (2.24) and (2.24a), it can be seen that growth is export biased $\left(\mathrm{R}_{1 \mathrm{~V}}{ }^{\mathrm{A}}<0\right)$ and welfare reducing. In other words, growth is immiserizing. 


\subsection{The model: capital transfers, taxes and welfare}

For simplicity, we will assume that all the income generated by the foreign capital accrues to the recipient and is not repatriated. Furthermore, since we a dealing with a factor transfer, we ignore factor price equalization. We use the same notation as in section 2.2, and ignore financial transfers. The expenditure-revenue identities of the two nations are:

$$
\begin{aligned}
& E^{A}\left(p(1-t), 1, U^{A}\right)=R^{A}\left\{p(1-t), 1, K^{A}+K^{I}\right\}+t p\left(R_{1}^{A}-E_{1}^{A}\right) \\
& E^{B}\left(p, 1, U^{B}\right)=R^{B}\left(p, 1, K^{B}-K^{I}\right)
\end{aligned}
$$

The market clearing equation for good-1 is:

$\mathrm{E}_{1}^{\mathrm{A}}\left(\mathrm{p}(1-\mathrm{t}), 1, \mathrm{U}^{\mathrm{A}}\right)+\mathrm{E}_{1}^{\mathrm{B}}\left(\mathrm{p}, 1, \mathrm{U}^{\mathrm{B}}\right)=\mathrm{R}_{1}^{\mathrm{A}}\left\{\mathrm{p}(1-\mathrm{t}), 1, \mathrm{~K}^{\mathrm{A}}+\mathrm{K}^{\mathrm{I}}\right\}+\mathrm{R}_{1}^{\mathrm{B}}\left(\mathrm{p}, 1, \mathrm{~K}^{\mathrm{B}}-\mathrm{K}^{\mathrm{I}}\right)$.

Equations (2.25) through (2.27) determine $\mathrm{U}^{\mathrm{A}}, \mathrm{U}^{\mathrm{B}}$ and $\mathrm{p}$ as functions of the export tax rate $\mathrm{t}$ and the capital transfer $\mathrm{K}^{\mathrm{I}}$. As before, we solve the model recursively in the following manner. Relations (2.25) and (2.26) implicitly define (2.25a) and (2.26a) below, respectively:

$$
\begin{aligned}
& \mathrm{U}^{\mathrm{A}}=\mathrm{U}^{\mathrm{A}}\left(\mathrm{p}, \mathrm{t}, \mathrm{K}^{\mathrm{I}}\right) . \\
& \mathrm{U}^{\mathrm{B}}=\mathrm{U}^{\mathrm{B}}\left(\mathrm{p}, \mathrm{K}^{\mathrm{I}}\right) .
\end{aligned}
$$


Using (2.25a) and (2.26a) we have:

$$
\begin{aligned}
& \mathrm{E}_{1}^{\mathrm{A}}\left\{\mathrm{p}(1-\mathrm{t}), 1, \mathrm{U}^{\mathrm{A}}(.)\right\}+\mathrm{E}_{1}^{\mathrm{B}}\left\{\mathrm{p}, 1, \mathrm{U}^{\mathrm{B}}(.)\right\} \\
& =\mathrm{R}_{1}^{\mathrm{A}}\left\{\mathrm{p}(1-\mathrm{t}), 1, \mathrm{~K}^{\mathrm{A}}+\mathrm{K}^{\mathrm{I}}\right\}+\mathrm{R}_{1}^{\mathrm{B}}\left\{\mathrm{p}, 1, \mathrm{~K}^{\mathrm{B}}-\mathrm{K}^{\mathrm{I}}\right\}
\end{aligned}
$$

Relation-(2.27a) defines:

$$
p=p\left(t, K^{I}\right)
$$

From (2.27b) we obtain the terms of trade $\mathrm{p}$ as a function of the exogenous variables $t$ and $K^{I}$. Substituting for $p$ and using the values of $t$ andK $K^{I}$, we can solve for $\mathrm{U}^{\mathrm{A}}$ and $\mathrm{U}^{\mathrm{B}}$ from (2.25a) and (2.26a), respectively.

Differentiating (2.25a) we have:

$$
\mathrm{dU}^{\mathrm{A}}=\mathrm{U}_{1}^{\mathrm{A}} \mathrm{dp}+\mathrm{U}_{2}^{\mathrm{A}} \mathrm{dt}+\mathrm{U}_{3}^{\mathrm{A}} \mathrm{dK}
$$

The first term on the right hand side of (2.25b) captures the terms of trade effect. Using the implicit function theorem on (2.25), we can obtain an explicit expression of the terms of trade effect:

$$
\mathrm{U}_{1}^{\mathrm{A}}=\left[\left(\mathrm{R}_{1}^{\mathrm{A}}-\mathrm{E}_{1}^{\mathrm{A}}\right)+\operatorname{tp}(1-\mathrm{t})\left(\mathrm{R}_{11}^{\mathrm{A}}-\mathrm{E}_{11}^{\mathrm{A}}\right)\right] / \mathrm{D}^{\mathrm{A}}>0 ; \mathrm{D}^{\mathrm{A}}=\mathrm{E}_{3}^{\mathrm{A}}+\operatorname{tp}_{13}^{\mathrm{A}}>0 .
$$


The first term on the right hand side of the first equation in $(2.25 \mathrm{c})$ is the gain from exporting the existing level of exports at a higher price. The second term measures the gains in tax revenue from the expansion of exports.

The second term on the right hand side of (2.25b) measures the partial effect of the tariff on the welfare of nation A. Using the implicit function theorem on (2.25), this effect can be expressed as follows:

$\mathrm{U}_{2}^{\mathrm{A}}=\mathrm{p}\left\{\mathrm{tp}\left(\mathrm{E}_{11}^{\mathrm{A}}-\mathrm{R}_{11}^{\mathrm{A}}\right)\right\} / \mathrm{D}^{\mathrm{A}}<0$.

A rise in the export tax (for a given p) causes the usual production and consumption distortions by reducing the domestic price of good-1. Similarly, the direct effect of capital transfers on the welfare of nation $\mathrm{A}$ is measured by:

$\mathrm{U}_{3}^{\mathrm{A}}=\left(\operatorname{tpR}_{31}^{\mathrm{A}}+\mathrm{R}_{3}^{\mathrm{A}}\right) / \mathrm{D}^{\mathrm{A}}$.

This effect has an ambiguous sign. A capital transfer will reduce the production of good1. On the other hand, the return on capital is positive. It should be noted that if the export tax is zero, the direct effect of the capital transfer on welfare is positive. The presence of an export tax means that production of exports as well as consumption is distorted. Capital transfers add to these distortions by further contracting the export sector. As a result welfare is also further reduced.

Totally differentiating (2.27b) we have: 
$d p=p_{1} d t+p_{2} d K^{I}$

The direct effect of capital transfers on the terms of trade $\left(\mathrm{p}_{2}\right)$ can be obtained from (2.27a) and is given by:

$\mathrm{p}_{2}=\left\{\mathrm{R}_{13}^{\mathrm{B}}-\mathrm{R}_{13}^{\mathrm{A}}+\mathrm{E}_{13}^{\mathrm{A}} \mathrm{U}_{3}^{\mathrm{A}}+\mathrm{E}_{13}^{\mathrm{B}} \mathrm{U}_{2}^{\mathrm{B}}\right\} / \mathrm{MLC}<0 ; \mathrm{U}_{2}^{\mathrm{B}}=-\mathrm{R}_{3}^{\mathrm{B}} / \mathrm{E}_{3}^{\mathrm{B}}<0$.

MLC is the slope of the global excess supply function and is positive to ensure stability. In the absence of a trade tax, the sign of $\mathrm{p}_{2}$ is negative if the donor's marginal propensity to consume goodl is higher than the recipient's marginal propensity to consume good 1 (see for example, Brakeman and van Marrewijk, 1998). With an export tax, the negative effect of capital transfers on the terms of trade is only possible if $\operatorname{tpR}_{31}^{\mathrm{A}}>\mathrm{R}_{3}^{\mathrm{A}}$ in absolute terms. From Brecher and Bhagwati (1982), we know that in a two good, two country model with market stability, a transfer in the presence of a production distortion leads to a terms of trade distortion. Therefore $\operatorname{tp}_{31}^{\mathrm{A}}>\mathrm{R}_{3}^{\mathrm{A}}$ in absolute value.

Substituting (2.27c) into (2.25b) and simplifying we get:

$d U^{A}=\left(U_{1}^{A} p_{1}+U_{2}^{A}\right) d t+\left\{U_{1}^{A} p_{2}+\left(\operatorname{tpR}_{31}^{A}+R_{3}^{A}\right) / D^{A}\right\} d K^{I}$

From (2.25c), the effect of capital transfers on welfare is given by:

$$
\mathrm{dU}^{\mathrm{A}} / \mathrm{dK}=\mathrm{U}_{1}^{\mathrm{A}} \mathrm{p}_{2}+\operatorname{tpR}_{31}^{\mathrm{A}} / \mathrm{D}^{\mathrm{A}}+\mathrm{R}_{3}^{\mathrm{A}} / \mathrm{D}^{\mathrm{A}}
$$


From (2.28), it can be seen that capital transfers have a price effect, a production effect and an income effect. The first term on the right hand side of (2.28) is the price effect, the second term is the production effect and the last term is the income effect. Under free trade, welfare depends on the price effect and the income effect alone. We know from Samuleson (1947) that in this case, the income effect dominates the price effect and welfare improves as a result. With the trade distortion in (2.28), we know from Brecher and Bhagwati (1982) and Bandyopadhyay and Majumdar (2003) that the price effect and production effect overcome the income effect and the recipient suffers a net welfare loss. The recipient's welfare falls despite the fact that productive capacity and hence growth has been increased by the transfer of capital. Growth is therefore immiserizing.

\subsection{Summary and conclusions}

Many developing countries are highly dependent on foreign capital goods that are used in the import competing industrialized sector. The exporting sector focuses on primary products where land and labor are predominantly used. We build a two-good general equilibrium model, where the import competing sector uses foreign capital input. The model is used to theoretically analyze how financial transfers and capital transfers to a developing country affect the welfare of the developing country. In addition, we also analyze the welfare effect of foreign aid using simulations.

In the case of financial transfers, we find that such transfers induce changes in commodity terms of trade, which in turn affects capital inflows and the price of imported capital. If export taxes are taken to be exogenous, we find that endogenous capital flows aggravate the transfer problem that exists under trade taxation. When trade liberalization 
is tied to transfers, we find that the tying of aid may worsen or alleviate the transfer problem, depending on how the existing export tax compares with the optimum. To shed more light on the transfer problem in the context of trade liberalization tied to transfers, we solve the model numerically and conduct simulations. We find that the tying of aid results in a welfare loss for nation A, given the functional forms and parameter values used in carrying out the simulations.

In the case of capital transfers, we find that such transfers affect welfare through a price effect, a production effect and an income effect. The presence of a trade distortion causes the price effect and production effect to overcome the income effect. As a result, the recipient suffers a net welfare loss. The recipient's welfare falls despite the fact that productive capacity and hence growth has been increased by the transfer of capital. Growth is therefore immiserizing.

In conclusion, transfer paradoxes cannot be ruled out in the context of capital goods. If there is a trade distortion, untied transfers reduce welfare through a value effect (higher price of imported capital) and a volume effect (greater inflow of capital). Both the value effect and the volume effect are induced by the price effect of the transfer. The tying of financial transfers can also lead to a welfare loss. Capital transfers may reduce welfare by causing immiserizing growth. 
Table 2.1: model solution

\begin{tabular}{ll}
\hline Variable & Solution \\
\hline $\mathrm{t}$ & 0.1 \\
$\mathrm{U}^{\mathrm{A}}$ & $7.921402 \mathrm{E}+2$ \\
$\mathrm{P}_{1}$ & 0.59292090 \\
$\mathrm{P}_{1}(1-\mathrm{t})$ & 0.53362881 \\
$\mathrm{~K}^{\mathrm{I}}$ & $6.269433 \mathrm{E}+2$ \\
$\mathrm{C}_{1}{ }^{\mathrm{A}}$ & $1.742571 \mathrm{E}+3$ \\
$\mathrm{Q}^{\mathrm{A}}$ & $1.061184 \mathrm{E}+3$ \\
$\mathrm{D}^{\mathrm{A}}$ & $6.073102 \mathrm{E}+2$ \\
$\mathrm{r}^{\mathrm{A}}$ & 0.44519375 \\
$\mathrm{r}^{\mathrm{B}}$ & 0.44519375 \\
$\mathrm{EX}_{1}{ }^{\mathrm{A}}$ & $4.538737 \mathrm{E}+2$ \\
\hline
\end{tabular}

Table 2.2: simulation results with tied aid

\begin{tabular}{ll}
\hline Variable & Solution \\
\hline $\mathrm{t}$ & 0.09900990 \\
$\mathrm{U}^{\mathrm{A}}$ & $7.920902 \mathrm{E}+2$ \\
$\mathrm{U}^{\mathrm{B}}$ & 2.10919618 \\
$\mathrm{P}_{1}$ & 0.59249898 \\
$\mathrm{P}_{1}(1-\mathrm{t})$ & 0.53383571 \\
$\mathrm{~K}^{\mathrm{I}}$ & $6.283700 \mathrm{E}+2$ \\
$\mathrm{C}_{1}{ }^{\mathrm{A}}$ & $1.742488 \mathrm{E}+3$ \\
$\mathrm{Q}^{\mathrm{A}}$ & $1.062779 \mathrm{E}+3$ \\
$\mathrm{D}^{\mathrm{A}}$ & $6.079165 \mathrm{E}+2$ \\
$\mathrm{r}^{\mathrm{A}}$ & 0.44496945 \\
$\mathrm{r}^{\mathrm{B}}$ & 0.44496945 \\
$\mathrm{EX}_{1}{ }^{\mathrm{A}}$ & $4.548623 \mathrm{E}+2$ \\
\hline
\end{tabular}


Table 2.3: simulation results with untied aid

\begin{tabular}{ll}
\hline Variable & Solution \\
\hline $\mathrm{U}^{\mathrm{A}}$ & $7.922209 \mathrm{E}+2$ \\
$\mathrm{U}^{\mathrm{B}}$ & 2.10918620 \\
$\mathrm{P}_{1}$ & 0.59291899 \\
$\mathrm{P}_{1}(1-\mathrm{t})$ & 0.53362709 \\
$\mathrm{~K}^{\mathrm{I}}$ & $6.269942 \mathrm{E}+2$ \\
$\mathrm{C}_{1}{ }^{\mathrm{A}}$ & $1.742405 \mathrm{E}+3$ \\
$\mathrm{Q}^{\mathrm{A}}$ & $1.061119 \mathrm{E}+3$ \\
$\mathrm{D}^{\mathrm{A}}$ & $6.073724 \mathrm{E}+2$ \\
$\mathrm{r}^{\mathrm{A}}$ & 0.44519561 \\
$\mathrm{r}^{\mathrm{B}}$ & 0.44519561 \\
$\mathrm{EX}_{1}{ }^{\mathrm{A}}$ & $4.537468 \mathrm{E}+2$ \\
\hline
\end{tabular}




\section{CHAPTER 3}

\section{Transfers, Trade Taxes and Endogenous Capital Flows: An Empirical Analysis of Sub-Saharan Africa}

\subsection{Introduction}

Sub-Saharan Africa (SSA) is a region with 48 countries and had a total population of 688 million people in 2002. ${ }^{10}$ Most countries in Africa are located in this region. Exceptions are north African countries (Algeria, Egypt, Libya, Morocco, and Tunisia) which are considered to be part of the Middle East. ${ }^{11}$ The 48 countries are:

Angola, Benin, Botswana, Burkina Faso, Burundi, Cameroon, Cape Verde, Central African Republic, Chad, Comoros, Congo, Dem. Rep., Congo, Rep., Côte d'Ivoire, Equatorial Guinea, Eritrea, Ethiopia, Gabon, Gambia, Ghana, Guinea, Guinea-Bissau, Kenya, Lesotho, Liberia, Madagascar, Malawi, Mali, Mauritania, Mauritius, Mayotte Mozambique, Namibia, Niger, Nigeria, Rwanda, São Tomé and Principe, Senegal, Seychelles, Sierra Leone, Somalia, South Africa, Sudan, Swaziland, Tanzania, Togo Uganda, Zambia, and Zimbabwe.

Real GDP per capita in 2000 was US\$ 564, which places the majority of countries in the low income category. Exceptions are Namibia and South Africa which are classified as lower middle income economies and Botswana, Mauritius and Seychelles which are classified as upper middle income economies. The agricultural sector is the main sector of most economies. According to Helleiner (1994) and Sender (1999), about $65-70 \%$ of the population depends on the agricultural sector for employment and survival. The sector is also a major source of foreign exchange earnings. It contributes over $50 \%$ of total exports (Sender, 1999).

\footnotetext{
${ }^{10}$ The data profile for SSA described in this section was obtained from World Development Indicators (2003).

${ }^{11}$ A map of the political geography of Africa can be found in appendix I.
} 
Due to the fact that agriculture is the primary economic activity, the other sectors of the economy have backward and forward linkages with the agricultural sector. Exports of the region consist mainly of undiversified primary products. Given the importance of agriculture, most of these exports are agricultural products. West African countries such as Cameroon, Cote d' Ivoire, Ghana, and Nigeria are major exporters of cocoa. Cote d' Ivoire is also a major exporter of coffee, while Kenya is a major exporter of tea. Other important agricultural exports include cotton, tobacco and groundnuts.

As a consequence of colonialism, SSA has many small countries. Collier and Gunning (1999) estimate that SSA's population is approximately half that of India and is divided among the 48 states. The existence of such small economies implies that opportunities for realizing economies of scale and scope are very much limited. Consequently the region has to import capital goods and inputs necessary for development from abroad.

Since the 1980s, multilateral resource flows to Sub-Saharan Africa (SSA) have become the most important source of external finance that supports policy reforms. The objective of these policy reforms is to achieve sustained growth in per capita income that would provide the welfare gains needed to lift Africa out of poverty. Over and above supporting reforms, these transfers are by themselves an important source of income and hence welfare. From 1970 to 1980 , SSA's average GDP per capita growth was $1.23 \%$, from 1980 to 1990 , GDP per capita growth decelerated to $-0.78 \%$, and from 1990 to 2000 , GDP per capita growth was $-0.52 \% .^{12}$

On the other hand, total EDA to SSA was US\$23.7 from 1978 to 1981 . It fell slightly to US\$22.5 from 1982 to 1985 , and then rose to reach US\$30.7 from 1986 to

${ }^{12}$ Author's calculations based on data from World Development Indicators (2002). 
1989 before reaching a peak of US\$37.3 from 1990 to 1993 . Thereafter it declined slightly to US\$ 32.3 from 1994 to $1997 .^{13}$ Given these large transfers after 1980, one would expect to see positive welfare gains in SSA. How can we reconcile the economic stagnation with increased transfers? In order to understand the rationale for multilateral transfers and reforms in SSA and to evaluate their impact on welfare, it is useful to analyze the economic performance of the region in the period prior to the reforms and transfers and in the period after reforms and transfers.

\subsubsection{Sub-Saharan's economic performance prior to reforms}

Before 1970, SSA's enjoyed good economic performance. Based on Collier and Gunning (1999), SSA grew faster than Asia during the 1950s. The high growth was sustained in the 1960s, as the region increasingly became free of colonialism. However, starting from the 1970s, SSA experienced a decline in growth and is yet to recover from this economic decline.

A number of factors have accounted for SSA's economic stagnation between 1970 and 1980. Based on Ndulu (1991) and Wheeler (1984), these factors can be grouped under policy misdirection and exogenous factors. Key among the exogenous factors is terms of trade, weather and world interest rates. Exports are the major component of GDP in monocultural economies such as those in Zambia, Nigeria, Gabon, Congo, Mauritius and Ethiopia. The performance of exports is heavily influenced by the terms of trade, which are exogenous. Commodity terms of trade declined during this period because the demand for SSA exports was weakened by global recessions. The poor export performance adversely affected growth.

\footnotetext{
${ }^{13}$ The source of EDA data is Chang, Fernandez-Arias, and Serven (1998).
} 
In response to the weak export performance, many countries had to rely on external resources to meet import requirements. The increase in real interest rates on external debt during this period resulted in a diversion of resources from financing investment requirements to debt servicing. Shifting weather conditions have negatively affected growth because the region has many agro-based economies.

Policy misdirection was in the form of import allocation policy and anti-trade policies. According to Wheeler (1984), the trade regimes of SSA were characterized by trade barriers such as import quotas, import licensing, prohibitive tariffs and export taxes. While the trade regimes were suited to the goal of import substitution and raising revenue, they however discouraged exports. The combined effects of anti-export policies and the decline in terms of trade led to a balance of payments crisis. Most of the governments in SSA responded to the balance of payments crisis with an import compression policy. Imports of consumer goods were restricted and first priority was given to imports of capital goods followed by imports of intermediate goods. This import allocation policy is consistent with country studies for Tanzania by Ndulu (1986) and Zimbabwe by Davies (1991). Wheeler (1984) and Ndulu (1991) document the existence of an import allocation policy for the rest of the region.

The import allocation policy led to capacity expansion through increased investment. However, Ndulu (1991) notes that the new capacity was underutilized because it heavily depended on imported intermediate goods which were rationed. In addition, Ndulu (1991) also points out that the problem of capacity utilization was worsened by the lack of complementary investments in infrastructure and human capital. As a result, the import allocation policy was not effective in generating economic growth. 
The World Bank (1989) underscores the importance of expansionary monetary and fiscal policies as well as overvalued exchange rates as sources of economic stagnation during this period.

\subsubsection{Sub-Saharan Africa's economic performance in the reform period}

During the 1980s, many countries in SSA realized that policy reforms were necessary for economic recovery. As a result, SSA embraced IMF and World Bank economic reforms. Highly concessional transfers were provided by the World Bank's International Development Association (IDA) to finance the reforms. To enable the transfers and reforms to improve welfare, IDA emphasizes the following: ${ }^{14}$

a) Accelerating broad-based growth through sound macroeconomic and sectoral policies, especially for rural and private sector development.

b) Investing in people through strong support for the social sectors, including gender mainstreaming and efforts to counter the challenge and social impact of communicable diseases, especially HIV/AIDS.

c) Building capacity for improving governance - including in public expenditure management - and combating corruption.

d) Protecting the environment for sustainable development.

e) Fostering recovery in post-conflict countries.

f) Promoting trade and regional integration.

${ }^{14}$ This list of items is taken from the World Bank website. For a list of EDA borrowers in SSA, see appendix II. 
Concessional lending under the IMF is done under the Poverty Reduction and Growth Facility (PRGF), formerly known as the Enhanced Structural Adjustment Facility (ESAF). Article I of the IMF agreement summarizes the objectives of IMF concessioanl lending: $:^{15}$

a) To facilitate the expansion and balanced growth of international trade, and to contribute thereby to the promotion and maintenance of high levels of employment and real income and to the development of the productive resources of all members as primary objectives of economic policy.

b) To promote exchange stability, to maintain orderly exchange arrangements among members, and to avoid competitive exchange depreciation.

c) To assist in the establishment of a multilateral system of payments in respect of current transactions between members and in the elimination of foreign exchange restrictions which hamper the growth of world trade.

d) To give confidence to members by making the general resources of the Fund temporarily available to them under adequate safeguards, thus providing them with opportunity to correct maladjustments in their balance of payments without resorting to measures destructive of national or international prosperity.

e) In accordance with the above, to shorten the duration and lessen the degree of disequilibrium in the international balances of payments of members.

It is quite clear therefore that the policy reforms advocated by the IMF and World Bank consist of stabilization measures and adjustment measures. Stabilization measures include

\footnotetext{
${ }^{15}$ The listed items were obtained from the IMF website. For a list of countries in SSA that are eligible for PRGF, see appendix II.
} 
devaluation and complementary monetary and fiscal policies, while adjustment measures include resource mobilization, institutional reform and market liberalization.

According to Helleiner (1994), the economic reforms which were implemented in the 1980s were as follows:

(1) major currency devaluations;

(2) major real cuts and reorientation towards agriculture in the government budget;

(3) reorientation of public expenditures in the productive sectors towards rehabilitation and maintenance;

(4) increased taxes on consumer goods;

(5) raising nominal wages by significantly less than what is required to make up for the effects of inflation;

(6) liberalization of the import regime;

(7) substantially raising nominal producer prices for agricultural cash crops so as at least to limit real declines;

(8) reduced price controls;

(9) increased competition and flexibility in agricultural marketing; and

10) privatization of government-owned assets and concentrated efforts to raise efficiency in remaining governmental institutions.

It is now more than two decades since SSA embarked on economic reforms. During this period, the region has also received disproportionate amounts of multilateral transfers. The outcome of the transfers as well as the reforms in terms of progress towards restoring growth in per capita income is however disappointing. Africa remains the poorest continent in the world. Transfers and reforms have simply not delivered the expected 
welfare outcomes. That the standard of living is generally very poor is quite evident from the per capita income levels, which have grown much slower compared to the rest of the world.

Several factors have been put forward to explain the poor economic performance after 1980. Some of the exogenous factors continued to play an important role. Recurring droughts have reduced the output of a predominantly agricultural region. Deteriorating terms of trade have also been persistent. As Yeats (1997) put it:

..in 1962-64 copper alloys were the region's single largest commodity export, with Sub-Saharan Africa supplying 32 percent of all OECD imports. By 1991-93, however, Africa's market share had dropped more than 22 percentage points to less than 10 percent. Similarly, Africa's market shares for other key commodities (such as vegetable oils, palm oil, palm nuts and Kernels, and groundnuts) dropped 47-80 percentage points below earlier levels. For the thirty most important non-oil exports combined, Africa's average shares declined by more than 11 percentage points (from 20.8 percent to 9.7 percent), which implies annual trade losses of about $\$ 11$ billion... (Yeats, 1997, 1).

Exports and hence growth suffered as a result. Interestingly enough, the implementation of economic reforms in the 1980s is also blamed for the poor growth. According to Helleiner (1994), the major problems in the economic reforms were:

(i) over-reliance upon reform in incentive structures;

(ii) relative neglect of the provision of crucial public goods, especially in agricultural infrastructure;

(iii) naiveté about the nature of required changes in the financial system, particularly the efficacy of interest rate increases;

(iv) naiveté about the efficacy of privatization, especially in agricultural marketing and input distribution; 
(v) neglect of human capital and poverty;

(vi) over-optimism over the prospects for expansion of earnings from traditional exports;

(vii) under-funding, and inappropriate forms of external assistance; and

(viii) inadequate appreciation of the fiscal implication of reform packages incorporating sharp devaluations and interest rate increases.

Stiglitz (1998), Ndulu (1994), and Fischer and Corbo (1995) also discuss some of these factors.

The World Bank (1989) distinguishes between countries with strong reforms and countries with weak reforms. The following countries were classified as strong reformers:

Guinea-Bissau, Niger, Ghana, Madagascar, Zaire, Gambia, Mauritania, Senegal, Tanzania, Cote d'voire, Burundi, Congo, Kenya, Malawi, Nigeria, Togo, Guinea, Mauritius.

Countries classified as weak reformers were as follows:

Angola, Benin, Burkina, Cape Verde, Chad, Comoros, Djibouti, Equatorial Guinea, Ethiopia, Liberia, Mali, Mozambique, Sao Tome and Principe, Seria Leone, Somalia, Sudan, Uganda, Zambia, Zimbabwe.

Helleiner (1994) compares the GDP growth of the strong reformers and the weak reformers. The data does not show that strong reformers outperformed weak reformers as one would expect. This finding lends supports to Helleiner (1994)'s observation that there were major problems related to the reforms themselves.

There are of course other factors that could have caused SSA's lack of economic progress. There has been a plethora of empirical studies on this subject. Empirical studies 
that look at the welfare performance of SSA have taken two different approaches. Some studies have sought to explain cross-national differences in welfare while other studies analyze factors that explain the welfare of SSA as a region. Both approaches use per capita income as the measure of welfare. Studies that have followed the first approach include Rodrik (1998), Easterly and Levine (1997) and Sachs and Warner (1995, 1997). The second approach has been followed by the IMF (1996) and the World Bank (1981, 1994).

Based on available cross-national data for the whole world, Easterly and Levine (1997) explain why per capita income has remained much lower in SSA compared to the rest of the world. The reasons are low schooling, political instability, underdeveloped financial systems, distorted foreign exchange markets, high government deficits and poor infrastructure. Sachs and Warner $(1995,1997)$ also use a global data set, but reach a different conclusion. They argue that trade policies, geography and demography explain why per capita income in SSA has remained low at a time when the rest of the world is enjoying much higher per capita incomes. The combination of closed trade policies, a tropical climate (characterized by poor health, poor soils and unreliable rainfall patterns), many landlocked countries and high population growth is seen to have adversely affected the wellbeing of SSA.

Rodrik (1998) has analyzed variation in per capita income within SSA. According to his findings, the most important factors accounting for differentials in per capita income are: human resources (life expectancy), macro/fiscal policy (public savings), demography (changes in the dependency ratio), export policies (export taxes) and a catch-up/convergence factor (initial per-capita income). The IMF (1996) and the World 
Bank (1981, 1994) view policy mistakes as the key explanation for SSA's failure to grow.

\subsubsection{Objectives}

The fact that policy reforms in SSA seek to create competitive markets and get rid of distortions (among other things) means that until such reform initiatives have been successfully implemented, multilateral transfers may not be able to improve welfare since the Samuelsonian conditions are not met. In addition, the fact that multilateral aid is often tied to policy reform measures such as liberalization, stabilization and privatization raises the possibility of recipient impoverishment based on the arguments advanced by Kemp and Kojima (1985) and others. Could these be some of the reasons why SSA has still not seen growth in per capita income despite more than two decades of reforms (since the 1980s) $?^{16}$ Our paper addresses this question.

A crucial structural factor that affects the performance of SSA that has not been explicitly considered by the literature on the transfer problem is that investment and production are highly depended on imported capital goods such as machinery and transport equipment. Country studies by Wangwe (1983), Green and Kadhani (1986), and Davies and Rattso (1993) report a high degree of import dependency. A Sub-Saharawide study by Ndulu (1991) also finds a high degree of import dependency. Moran (1989) shows that dependency on imports of capital goods is a general characteristic of

16 The World Bank (2001) study on aid and reform in SSA classifies ten countries into four groups: successful reformers, post-socialist reformers, mixed reformers and non-reformers. Table 3.1 shows that most of the aid was given to the successful reformers, post-socialist reformers, and mixed reformers. It also shows that with the exception of Uganda, GDP per capita did not improve for other countries in these three groups just as it did not improve for the non-reforming countries. Group categories therefore do not tell us much about economic performance. Different starting points of reform and hence different durations of reforms (see Table 3.1) could be important in explaining differences in GDP per capita growth. 
poor developing countries. The study by Ndulu (1991) finds that the ratio of capital goods imports to investment for the whole of SSA has been stable around $36 \%$. This translates to very high ratios at the country level. For example, Green and Kadhani (1986) find that the ratio of capital goods imports to investment ranges between $65-75 \%$ for the manufacturing sector in Zimbabwe.

We build an econometric model and empirically analyze the transfer problem in the presence of an exogenous export tax and endogenous capital inflows. The empirical analysis borrows from the general equilibrium model developed in chapter 2, some of the existing literature discussed above and from Savvides (1995) and Barro (2000) who emphasize the importance of factors such as openness and inflation in contributing to the weak performance of SSA nations.

The empirical model and discussions related to data are presented in section 3.2. Estimation results are presented in section 3.3. Section 3.4 presents the summary and conclusions.

\subsection{Model specification and data description ${ }^{17}$}

The transfer problem in the presence of an exogenous export tax and endogenous capital inflows is analyzed empirically by estimating relations (2.1a), (2.3a) and (2.4b). Based on these relations, we can specify the following equations:

$$
\begin{aligned}
& \mathrm{U}^{\mathrm{A}}=\mathrm{a}_{0}+\mathrm{a}_{1} \mathrm{p}+\mathrm{a}_{2} \mathrm{t}+\mathrm{a}_{3} \mathrm{~K}^{\mathrm{I}}+\mathrm{a}_{4} \mathrm{~T}+\mathrm{e}_{1} \\
& \mathrm{~K}^{\mathrm{I}}=\mathrm{b}_{0}+\mathrm{b}_{1} \mathrm{p}+\mathrm{b}_{2} \mathrm{t}+\mathrm{e}_{2}
\end{aligned}
$$

\footnotetext{
${ }^{17}$ It is important to note that due to data problems we use import tariffs rather than export taxes in the empirical analysis. However, by virtue of the Lerner symmetry theorem, there is no harm in treating them similarly, because a reduction of an export tax or an import tariff has analogous effects on prices, trade volumes and welfare.
} 
$\mathrm{p}=\mathrm{c}_{0}+\mathrm{c}_{1} \mathrm{t}+\mathrm{c}_{2} \mathrm{~T}+\mathrm{e}_{3}$

$\mathrm{U}^{\mathrm{A}}$ is measured by the change in real GDP of nation-A. We were unable to obtain data on imports of capital goods. However, we know from Ndulu (1991) that the ratio between real imports of capital goods and real investment for SSA was stable around $36 \%$ over the 1980s decade. Based on this ratio and using data on real gross capital formation (GCF) for real investment, we calculated real imports of capital goods $\left(\mathrm{K}^{\mathrm{I}}\right)$. Since our data set covers mostly the 1980 s, estimated data on real capital goods imports should be close to the actual data. Foreign investment is calculated as the change in real imports of capital goods $\left(\Delta \mathrm{K}^{\mathrm{I}}\right)$.

We measure $p$ using the terms of trade. This is because the terms of trade is the relative price of exports and is given by the ratio of the export price index to the corresponding import price index. $\mathrm{T}$ is real aid disbursed by the multilateral institutions. It is based on the World Bank (1998)'s new approach to measuring aid flows called Effective Development Assistance (EDA). EDA is an aggregate measure of aid flows combining total grants and the grant equivalents of all official loans. ${ }^{18}$ The GDP deflator was used to calculate real disbursements of multilateral EDA. Data on other exogenous variables that affect the model are used to carry out robustness checks. Variables used for the robustness checks are openness (open), growth and inflation (inf). Openness is measured by trade as a percent of GDP and it affects $\mathrm{p}$ and $\mathrm{U}^{\mathrm{A}}$. Inflation also affects

\footnotetext{
${ }^{18}$ For more details about EDA, see Charles C. Chang, Eduardo Fernandez-Arias, and Luis Serven (1998).
} 
$\mathrm{U}^{\mathrm{A}} \cdot{ }^{19}$ The variable growth refers to GDP per capita growth (annual \%) and it affects $\Delta \mathrm{K}^{\mathrm{I}}$. In addition, we use real imports as one of the instrumental variables.

Average tariff rates (unweighted) were obtained from the World Bank's International Trade and Development dataset. Data on multilateral aid is from Chang, Fernandez-Arias, and Serven (1998). The rest of the data were obtained from the World Bank's Global Development Network Growth dataset and World Development Indicators' (2002). Data is available for 14 countries in Sub-Saharan Africa for the period 1980-1995. ${ }^{20}$ Rodrik (1998), Helleiner (1994) and Ghai (1987) suggest that there are important idiosyncratic or country specific factors as well as aggregate factors that affect income in SSA. To account for this heterogeneity across countries and through time, we use a two-factor model for panel data. We assume fixed effects. The two-way or two-factor model with fixed effects can be estimated by OLS. The estimation procedure creates dummy variables that capture the fixed effects. We use instrumental variables to avoid the problem of endogeneity bias. In the theoretical model presented in section-2, $\mathrm{T}$ is assumed to be exogenous. This assumption does not hold empirically as shown by Frey and Schneider (1986). In the estimation, T lagged is used as an instrument for T. Terms of trade and real capital goods imports are endogenous in the model. Lagged terms of trade are used as an instrument for terms of trade and real imports are used as an instrument for real capital goods imports.

\footnotetext{
${ }^{19}$ In the literature, it has been shown that inflation and openness affect growth (see for example Savvides (1995), Rodrik (1998), and Barro (2000)). We therefore expect these variables to also affect changes in real GDP.

${ }^{20}$ The countries are: Burkina Faso, Cameroon, Cote d'Ivoire, Ghana, Kenya, Malawi, Madagascar, Mauritius, Mali, Nigeria, Senegal, Uganda, Zambia, and Zimbabwe.
} 


\subsection{Model estimation and results}

Table 3.2 reports the results obtained for equation (3.3). Foreign aid causes a significant reduction in the terms of trade as predicted by theory. The results also show that tariffs significantly reduce the terms of trade. This is because tariffs increase the price of imports relative to the price of exports. The instrument used in the estimation (T-lagged) has the desirable properties: it is highly correlated with $\mathrm{T}$ (the correlation between $\mathrm{T}$ and $\mathrm{T}$ lagged is 0.71 ) and uncorrelated with the residuals (the correlation between $\mathrm{T}$ lagged and residuals is -0.12.). Results for equation (3.2) are shown in table 3.3. The terms of trade are significant and negatively affect capital inflows as predicted by the theoretical model. Tariffs have a positive effect on capital inflows. The reason is that higher tariffs encourage domestic production of importable goods. Since production of importables requires foreign capital, there is an increased inflow of foreign capital goods to expand production of the importable goods. The effect of tariffs on capital inflows is however insignificant.

We use terms of trade lagged as an instrument in the estimation. The correlation between terms of trade lagged and terms of trade is 0.89 and the correlation between terms of trade lagged and the residuals is 0 . Terms of trade lagged are therefore a good instrument to use. Table 3.4 reports the results for equation (3.1). An improvement in terms of trade raises welfare, but is not significant. Liberalizing trade by reducing tariffs has a negative effect on welfare as expected. The effect is however insignificant. Inflows of foreign capital are significant and they reduce welfare as predicted by the theoretical model. Finally, foreign aid has a positive effect on welfare as expected. This is the positive income effect of a transfer. The income effect is however not significant. In the 
estimation, real imports are used as an instrument for foreign capital. For terms of trade and foreign aid, the instruments are as before. The correlation between real imports and foreign capital is 0.68 and the correlation between real imports and residuals is 0 . Real imports are therefore a good instrument to use and so are the other two instruments. The correlation between terms of trade lagged and residuals is 0 and the correlation between aid lagged and residuals is 0.01 .

Robustness checks are performed by adding other exogenous variables to the model, testing for multicollinearity and analyzing the effect of dropping some countries from the analysis. Equations (3.1) to (3.3) are augmented as follows: ${ }^{21}$

$$
\begin{aligned}
& \mathrm{U}^{\mathrm{A}}=\mathrm{a}_{0}+\mathrm{a}_{1} \mathrm{p}+\mathrm{a}_{2} \mathrm{t}+\mathrm{a}_{3} \mathrm{~K}^{\mathrm{I}}+\mathrm{a}_{4} \mathrm{~T}+\mathrm{a}_{5} \text { open }+\mathrm{a}_{6} \inf +\mathrm{e}_{1} \\
& \mathrm{~K}^{\mathrm{I}}=\mathrm{b}_{0}+\mathrm{b}_{1} \mathrm{p}+\mathrm{b}_{2} \mathrm{t}+\mathrm{b}_{3} \text { growth }+\mathrm{e}_{2} \\
& \mathrm{p}=\mathrm{c}_{0}+\mathrm{c}_{1} \mathrm{t}+\mathrm{c}_{2} \mathrm{~T}+\mathrm{c}_{3} \text { open }+\mathrm{e}_{3}
\end{aligned}
$$

The same procedure is used to estimate equations (3.1a) to (3.3a). Table 3.2a reports the results for equation (3.3a). The results are robust. Increased openness significantly reduces terms of trade. The reason is that our sample consists of small open economies specializing in primary commodity exports which have generally experienced deteriorating terms of trade. ${ }^{22}$

Results for equation (3.2a) are shown in table 3.3a. The effects of terms of trade and tariffs on capital inflows are robust. Growth is significant and is positively related to

\footnotetext{
${ }^{21}$ Sachs and Warner $(1995,1997)$ show (using a dummy variable) that countries with access to the sea perform better than landlocked countries. Savvides (1995) shows that political freedom (measured by indices of political rights and civil liberties) also affects the performance of SSA. In unreported regressions, we find these factors to be insignificant. This could be due to the fact that we do not estimate a growth regression like the other studies. We also experimented with colonialism (measured as the number of years under colonialism) but this was not significant as well.

${ }^{22}$ See for example Ndulu (1991) and Wheeler (1984).
} 
capital inflows. This is because higher growth tends to attract more investment. Finally, the results for equation (3.1a) are shown in table 3.4a. The results are robust and have improved in terms of significance. Terms of trade are now significant. Both openness and inflation are significant. Greater openness improves welfare as expected. ${ }^{23}$ Inflation hurts welfare by creating an unstable macroeconomic environment. The correlation matrices of exogenous variables for the different estimations show that multicollinearity is not a problem. According to the World Bank (2001), Uganda's growth has been stronger than other reforming SSA countries. We exclude it from the sample and find that the results are robust. Excluding larger countries like Nigeria also does not overturn the results. It does not appear therefore that certain countries are driving the results. ${ }^{24}$

To sum up, our empirical results show that multilateral transfers significantly reduce terms of trade. The reduction in terms of trade significantly induces foreign capital inflows. Increased capital inflows and terms of trade deterioration significantly offset the real GDP gains from multilateral transfers. The results are consistent with the theoretical analysis in chapter 2 and are robust.

\subsection{Summary and conclusions}

The poor performance of Sub-Saharan Africa has been attributed to bad luck caused by exogenous factors and policy misdirection. Attempts at structural transformation through stabilization and adjustment programs has not led to economic recovery. Inflows of multilateral transfers into the region have also not delivered the expected welfare outcomes. A number of explanations have been offered to explain why

\footnotetext{
${ }^{23}$ See for example, Sachs and Warner $(1995,1997)$.

${ }^{24}$ The results for multicollinearity checks and sensitivity to country selection are not reported, but are available upon request.
} 
SSA has failed to grow and thereby enhance its welfare despite implementing reforms and receiving external financial support. None of these explanations have analyzed transfers and welfare in the context of imported capital goods.

SSA is highly dependent on imported capital goods that are used in the import competing industrialized sector. The exporting sector focuses on primary products where land and labor are predominantly used. We build an econometric model and empirically analyze the transfer problem in the presence of an exogenous export tax and endogenous capital inflows. This is done by estimating a regression model with fixed effects for a panel of 14 countries in SSA. Our empirical results show that multilateral transfers significantly reduce terms of trade. The reduction in terms of trade significantly induces foreign capital inflows. Increased capital inflows and terms of trade deterioration significantly offset the real GDP gains from multilateral transfers. The results are consistent with the theoretical analysis in chapter 2 and are robust.

To conclude, our results suggest that an additional factor may be relevant in explaining why SSA's welfare failed to improve. In the presence of capital imports, the price effect leads to a volume effect (greater inflow of capital). Both the price effect and the volume effect offset the income effect. Consequently overall welfare will fall if the income effect is dominated by the other two effects. 
Table 3.1: Aid Per Capita (U.S. dollars) and GDP Per Capita Growth (\%) for Selected Countries in SSA, 1982-97

\begin{tabular}{|c|c|c|c|c|c|}
\hline & $\begin{array}{l}\text { Start of } \\
\text { Reform }\end{array}$ & $1982-85$ & $1986-89$ & $1990-93$ & $1994-97$ \\
\hline \multicolumn{6}{|c|}{ Successful Reformers } \\
\hline \multicolumn{6}{|c|}{ Aid per capita } \\
\hline Ghana & 1983 & 12.2 & 34.3 & 35.2 & 31.4 \\
\hline Uganda & 1987 & 13.6 & 22.0 & 35.4 & 26.3 \\
\hline \multicolumn{6}{|c|}{ GDP per capita growth } \\
\hline Ghana & 1983 & -2.79 & 1.41 & 1.12 & 1.82 \\
\hline Uganda & 1987 & -1.22 & 1.91 & 2.43 & 4.66 \\
\hline \multicolumn{6}{|c|}{ Post-Socialist Reformers } \\
\hline \multicolumn{6}{|l|}{ Aid per capita } \\
\hline Ethiopia & 1991 & 10.3 & 16.0 & 19.9 & 15.1 \\
\hline Mali & & 32.1 & 46.7 & 46.0 & 47.4 \\
\hline Tanzania & 1986 & 26.9 & 39.8 & 39.3 & 29.6 \\
\hline \multicolumn{6}{|c|}{ GDP per capita growth } \\
\hline Ethiopia & 1991 & -1.41 & 0.73 & -0.06 & 0.84 \\
\hline Mali & & -0.89 & -0.78 & -1.23 & 1.80 \\
\hline Tanzania & 1986 & & & -0.40 & 0.40 \\
\hline \multicolumn{6}{|l|}{ Mixed Reformers } \\
\hline \multicolumn{6}{|l|}{ Aid per capita } \\
\hline Cote d'Ivoire & 1981 & 11.7 & 21.6 & 36.8 & 74.2 \\
\hline Kenya & 1980 & 28.4 & 30.2 & 34.5 & 24.5 \\
\hline Zambia & 1983 & 37.4 & 54.1 & 82.0 & 111.7 \\
\hline \multicolumn{6}{|c|}{ GDP per capita growth } \\
\hline Cote d'Ivoire & 1981 & -4.11 & -1.83 & -3.66 & 2.28 \\
\hline Kenya & 1980 & -1.32 & 2.59 & -1.51 & 0.74 \\
\hline Zambia & 1983 & -3.87 & -0.83 & -1.83 & -2.90 \\
\hline \multicolumn{6}{|l|}{ Non-Reformers } \\
\hline \multicolumn{6}{|l|}{ Aid per capita } \\
\hline DR Congo & Not started & 9.4 & 15.0 & 8.9 & 4.9 \\
\hline Nigeria & Not started & 0.7 & 1.4 & 2.1 & 1.4 \\
\hline \multicolumn{6}{|c|}{ GDP per capita growth } \\
\hline DR Congo & Not started & -1.36 & -1.65 & -12.74 & -5.63 \\
\hline Nigeria & Not started & -3.23 & 1.72 & 1.56 & -0.50 \\
\hline
\end{tabular}

Source: Data on aid per capita is from World Bank (2001).

GDP per capita growth figures are from World Development Indicators, World Bank (2002). 
Table 3.2: Equation (3.3) with two-way fixed effects

(Dependent variable $=$ terms of trade $(p)$ )

\begin{tabular}{ccc}
\hline Explanatory Variable & $\begin{array}{c}\text { Estimated } \\
\text { Coefficient }\end{array}$ & Significance Level \\
\hline Real aid (T) & -9.873 & .0000 \\
& $(-4.923)$ & \\
Import tariffs (t) & -1.427 & .0042 \\
constant & $(-2.894)$ & .0000 \\
& 150.264 & \\
\hline
\end{tabular}

Adjusted R-squared $=0.48$

$\mathrm{t}$-statistics are in parentheses.

Table 3.3: Equation (3.2) with two-way fixed effects

(Dependent variable $=$ foreign investment $\left(\Delta \mathrm{K}^{\mathrm{I}}\right)$ )

\begin{tabular}{ccc}
\hline $\begin{array}{c}\text { Explanatory } \\
\text { Variable }\end{array}$ & $\begin{array}{c}\text { Estimated } \\
\text { Coefficient }\end{array}$ & Significance Level \\
\hline Terms of trade $(\mathrm{p})$ & -1.010 & .0000 \\
& $(-4.461)$ & .6381 \\
Import tariffs $(\mathrm{t})$ & .810 & \\
& $(.471)$ & .1045 \\
constant & 89.670 & \\
& $(1.630)$ & \\
\hline
\end{tabular}

Adjusted R-squared $=0.07$

t-statistics are in parentheses.

Table 3.4: Equation (3.1) with two-way fixed effects (Dependent variable $=\Delta G D P$ )

\begin{tabular}{ccc}
\hline $\begin{array}{c}\text { Explanatory } \\
\text { Variable }\end{array}$ & $\begin{array}{c}\text { Estimated } \\
\text { Coefficient }\end{array}$ & Significance Level \\
\hline Terms of trade $(\mathrm{p})$ & $\begin{array}{c}1.377 \\
(1.199)\end{array}$ & .2319 \\
Import tariffs $(\mathrm{t})$ & $\begin{array}{c}-.896 \mathrm{E}-01 \\
(-.015)\end{array}$ & .9881 \\
& -.129 & .0000 \\
Foreign capital $\left(\mathrm{K}^{\mathrm{I}}\right)$ & $(-8.067)$ & .3997 \\
Real aid $(\mathrm{T})$ & 22.076 & \\
& $(.844)$ & .2527 \\
constant & 244.914 & \\
\end{tabular}

Adjusted R-squared $=0.38$

$t$-statistics are in parentheses. 
Table 3.2a: Equation (3.3a) with two-way fixed effects (Dependent variable $=$ terms of trade $(p)$ )

\begin{tabular}{ccc}
\hline Explanatory Variable & $\begin{array}{c}\text { Estimated } \\
\text { Coefficient }\end{array}$ & Significance Level \\
\hline Real aid (T) & -8.400 & .0001 \\
Import tariffs (t) & $(-4.106)$ & .0062 \\
& -1.342 & \\
openness & $(-2.762)$ & .0072 \\
& -.489 & \\
constant & $(2.713)$ & .0000 \\
& 172.360 & \\
& $(12.010)$ &
\end{tabular}

Adjusted R-squared $=0.50$

t-statistics are in parentheses.

Table 3.3a: Equation (3.2a) with two-way fixed effects (Dependent variable $=$ foreign investment $(\Delta \mathrm{K})$ )

\begin{tabular}{ccc}
\hline $\begin{array}{c}\text { Explanatory } \\
\text { Variable }\end{array}$ & $\begin{array}{c}\text { Estimated } \\
\text { Coefficient }\end{array}$ & Significance Level \\
\hline Terms of trade $(\mathrm{p})$ & -.973 & .0000 \\
& $(-4.328)$ & \\
Import tariffs $(\mathrm{t})$ & .910 & .5776 \\
& $(.558)$ & \\
growth & 5.986 & .0005 \\
& $(3.558)$ & \\
constant & 83.109 & .1148 \\
& $(1.583)$ & \\
\hline
\end{tabular}

Adjusted R-squared $=0.18$

t-statistics are in parentheses. 
Table 3.4a: Equation (3.1a) with two-way fixed effects

(Dependent variable $=\Delta G D P$ )

\begin{tabular}{ccc}
\hline $\begin{array}{c}\text { Explanatory } \\
\text { Variable }\end{array}$ & $\begin{array}{c}\text { Estimated } \\
\text { Coefficient }\end{array}$ & Significance Level \\
\hline Terms of trade $(\mathrm{p})$ & 2.531 & .0339 \\
& $(2.135)$ & .9076 \\
Import tariffs $(\mathrm{t})$ & .687 & .0000 \\
Foreign capital $\left(\mathrm{K}^{\mathrm{I}}\right)$ & $-.116)$ & .7482 \\
Real aid $(\mathrm{T})$ & $(-8.682)$ & .0035 \\
& 8.599 & \\
openness & $(.321)$ & 0585 \\
Inflation & 7.000 & \\
& $(2.955)$ & .4116 \\
constant & -1.966 & \\
& $(-1.902)$ & \\
\end{tabular}

Adjusted R-squared $=0.40$

t-statistics are in parentheses. 


\section{CHAPTER 4}

\section{Trade Liberalization, Underemployment and Welfare: Is there a Conflict?}

\subsection{Introduction}

Underemployment or labor under-utilization is a problem that exists in all economies. In developing countries where the problem affects the majority of the population, low unemployment rates can be misleading indicators of economic performance. The problem of underemployment is reflected by two labor market phenomenon. Firstly, its presence can be observed when there are individuals who engage in economic activities which do not suit their skill level. Secondly, underemployment is present when the hours of work for an individual are not enough and the individual is willing to engage in alternative forms of employment that have more hours of work.

Therefore underemployment can be either skill related or time related. The ILO uses the time related measure of underemployment. According to the ILO (2002), persons in time related underemployment must satisfy the following three criteria; ${ }^{25}$

(1) willingness to work additional hours;

(2) available to work additional hours; and

(3) worked less than a threshold relating to working time.

Willingness to work additional hours implies that an individual wanted another job in addition to their current job to increase their total hours of work; to replace any of their current jobs with another job with increased hours of work; to increase the hours of work

\footnotetext{
${ }^{25}$ Definitions of these criteria are taken from the ILO (2002).
} 
in any of their current jobs; or a combination of the above. It should be noted that individuals who have actively sought to work additional hours are distinguished from those who have not.

Available to work additional hours means that an individual is ready, within a specified subsequent period, to work additional hours, given opportunities for additional work. Worked less than a threshold relating to working time means that a person whose hours actually worked in all jobs during the reference period, was below a threshold. This threshold may be determined by the boundary between full-time and part-time employment, median values, averages, or norms for hours of work as specified in relevant legislation, collective agreements, and agreements on working time arrangement or labor practices in countries.

These two forms of underemployment are interrelated. Both represent low levels of productivity relative to what would be obtained under alternative employment situations. The presence of either form of underemployment is of concern for economic and social reasons. From an efficiency point of view, the fact that part of the labor force is underutilized reduces welfare as will be shown later. In fact, economic development does not make sense if it does not provide people with the opportunity to be productively employed and thereby raise their welfare. Socially, underemployment is undesirable because it implies low earnings among the affected individuals which lead to poor living standards. In developing countries, this problem is reflected in low life expectancy and the high incidence of health and social maladies. 
Existing literature on the effects of trade liberalization reforms in developing countries has focused on unemployment or employment but not on underemployment. Harrison and Hanson (1999) discuss the small impact that trade liberalization has had on employment in developing countries. They regard this small employment response as a puzzle because trade liberalization is expected to result in a large reallocation of employment from import-competing sectors to labor intensive export oriented sectors of the economy.

Studies done on Mexico and Morocco find that trade reform in the 1980s had very little effect on employment. Revenga (1997) for example finds that the reduction in Mexican tariffs and quotas did not cause the anticipated employment changes. Her estimates show that tariff reductions had no effect on employment at all. Quota reductions were significant, but caused a very small effect: she reports that a reduction in quotas by $80 \%$ resulted in a 2 to $3 \%$ fall in employment. Currie and Hanson (1997) analyzed the effect of trade reform in Morocco. They find that in most sectors, employment was not affected by lowering tariffs and quotas.

In a review of the empirical literature on trade orientation, liberalization and unemployment, Edwards (1993) highlights the importance attached to the effect of trade reform on short-term employment and long-run employment. The NBER study by Krueger (1983) analyzes the linkages between trade policy and employment in 10 developing countries. The study focused on measuring the labor intensity of the export sector and the import competing sector. It also measured the contribution of protection in causing a shift towards the capital intensive import-competing sector. Krueger (1983) 
concludes that trade liberalization would lead to increased employment as labor migrates to the labor intensive export sector.

Multilateral lending institutions emphasize trade liberalization in order to deal with the unemployment/employment problem in developing countries. For example, World Bank studies by Balassa (1982), Michaely et al (1991) and the IMF (1993) analyze the consequences of trade liberalization on employment or unemployment.

The widespread focus on trade liberalization and unemployment or employment while important does not, in isolation, shed light on the wider problem of inadequate use of a nation's human resources. If underemployment is very high, then employment per se is not the issue, and in such a case it is not surprising to get a weak employment response. This is not to deny that other factors such as adjustment costs are important. Our point is that underemployment is so pervasive in developing countries that it does not make sense to look at employment in isolation.

In the context of a small open economy, underemployment is not a problem if real wages are flexible and labor is homogeneous and inter-sectorally mobile. Under these conditions, the real product wage in the export sector is expected to fall relative to the real product wage in the import-competing sector following the liberalization of trade by reducing trade taxes. As a result, the export sector will expand relative to the importcompeting sector. These changes will decrease employment in the import-competing sector and increase employment in the export sector. ${ }^{26}$

Since the labor market is assigned a central role during trade liberalization, it is useful to analyze the structure and functioning of labor markets in a small open economy.

\footnotetext{
${ }^{26}$ The expansion of the export sector relative to the import-competing sector under trade liberalization is justified on the grounds that it improves welfare by removing production and consumption distortions that are caused by trade taxes (see for example, Krugman and Obstfeld, 2003).
} 
Based on Agenor (1996), there are three main sectors in the labor market; a rural sector, an informal urban sector and a formal urban sector. The rural sector is made up of selfemployed persons and unpaid family workers. Self employed persons are also in the informal sector. They include small traders, taxi drivers, street vendors (and so on) as well as privately owned small businesses producing services and non-tradable goods. Although this sector relies mostly on family labor, it occasionally relies on paid labor. Employees have no formal contracts and benefits, job insecurity is high and labor productivity is low. Wages are flexible and the sector is not unionized. Government regulations are not enforced in this sector and low productivity gives rise to underemployment.

In contrast, the formal sector consists of medium and large enterprises which produce both tradables and non-tradables. It employs both skilled and unskilled labor. Employees have formal contracts and government regulations require employers to provide benefits such as pensions, health insurance, and job security to employees. Wages are determined on the basis of productivity, collective bargaining, or government regulations such as minimum and maximum wage policies.

The labor market institutions and regulations have important implications for the functioning of labor markets. Hiring and firing regulations protect workers in the formal sector and make it difficult for employers to lay off workers. Non-wage labor costs add to this labor market rigidity. In addition, minimum wage laws, trade unions and productivity considerations affect the flexibility of wages. 
The problem of low labor absorption in many developing countries was the result of policies which were biased towards development of the formal sector alone. According to Mhone (2000), the main policy biases were as follows:

(a) Regulatory policies that gave the legal advantage to large firms in the formal sector with respect to accessing finance and various government benefits such as subsidies, export markets and services, including the regulation of prices and markets;

(b) Government expenditure policies that effectively subsidized large capital intensive firms;

(c) Various implicit and explicit subsidies that cheapened the relative cost of capital through skewed tariff and customs policies, credit provision, foreign exchange policies, education and training policies, research and development policies, provision of utilities, transport infrastructure, storage facilities, and so on; and

(d) Labor market outcomes which reinforced the tendency toward capital intensity, either as a consequence of union action or government regulation.

These policies therefore benefited the formal sector and acted against the other two sectors. The outcome of the policies had important implications for labor absorption. Based on Mhone (2000), some of these outcomes were as follows:

(1) The tendency towards low employment elasticity with respect to output and investment. In some developing countries in SSA, these elasticity are less than one percent. Given that GDP growth rates in SSA are less than five percent and population growth rates are about three percent per annum, the nature of the labor absorption problem is very evident. 
(2) The tendency toward excess capacity given the shortfall in aggregate demand.

(3) The fact that small scale firms and micro-enterprises had to override insurmountable barriers to be successful, and often with very little support from the government. In addition, given the limited labor absorption rates in the formal sector, the non-formal sector tends to be the employer of last resort for survival. Importance in this respect is the lateral expansion that results from ease of entry in the informal sector, which tends to depress labor returns. Also, informal sector enterprises attempting to engage in productive activities have to contend with a cost disadvantage since, unlike firms in the formal sector, they lack access to discount facilities with respect to finance, inputs, and markets.

(4) The absence of employment opportunities in the formal sector and saturation in informal sector activities led to low income and low productivity in the informal sector as reflected by long hours of work and very low wages.

These outcomes help to explain why underemployment is so pervasive and is a serious problem in developing countries.

The functioning of labor markets in developing countries has important implications for trade reforms. As noted by Forteza and Rama (2001):

"But if real wages cannot be cut...the reallocation process would take much longer than with a flexible labor market, and it could be associated with high unemployment or under-employment (p.2).” 
In addition, the labor market institutions and relocation costs may prevent instantaneous inter-sectoral labor mobility. As discussed above, labor is not homogeneous. A typical small open economy is characterized by an export sector that is intensive in the use of unskilled labor and an import-competing sector that is intensive in the use of skilled labor. ${ }^{27}$ Furthermore, the export sector is more labor intensive and the import-competing sector is more capital intensive. Also, real wages are not fully flexible as discussed above. Akerlof and Yellen (1986) observe that in general most markets seem to clear, but not the labor market. Real wages generally seem to be rigid.

We present a general equilibrium trade model that explicitly takes into account the employment structure and wage inflexibility of a typical small open economy. The model has two sectors; a labor-intensive export sector and a capital-intensive importcompeting sector. Real wages are assumed to be flexible in the export sector and rigid in the import-competing sector. The rigidity of real wages in the import-competing sector is endogenously determined on the basis of the efficiency wage hypothesis. ${ }^{28}$ Efficiency wage studies such as Shapiro and Stiglitz (1984), Foster and Wan (1984), Akerlof (1982) and Weiss (1980) provide strong evidence that real wage rigidity can be explained by endogenous factors. Real wage rigidity in the skilled sector results in underemployment. The model is used to analyze the effect of trade liberalization on underemployment and welfare.

Our analysis shows that liberalizing trade by reducing export taxes results in sectoral shifts that increase underemployment. The effect on welfare is ambiguous. In

\footnotetext{
${ }^{27}$ These features of a small open economy are based on Knight (1976) and Krueger (1983).

${ }^{28}$ Based on Akerlof and Yellen (1986), the efficiency wage hypothesis argues that firms care about labor productivity which is a function of the real wage paid. Firms may therefore find it profitable to keep wages above equilibrium in the presence of involuntary unemployment.
} 
fact, free trade is not optimal: we find that a small export tax leads to a welfare improvement. We complement the theoretical analysis with an empirical analysis of the effect of trade liberalization on underemployment. This is done by estimating a regression model with fixed effects for a panel of 19 developing economies. The empirical results show that trade liberalization significantly reduces employment in the skilled sector. Robustness checks give the same result. The result provides indirect evidence that trade liberalization increases underemployment as explained by the theoretical model.

The rest of this chapter is organized as follows. Section 4.2 discusses in detail the theoretical model and theoretical analysis. The model specification and data used are discussed in section 4.3. Section 4.4 explains model estimation and empirical results. Concluding remarks are given in Section 4.5.

\subsection{The Model: export taxes, underemployment and welfare}

Assume a small open economy that produces and consumes two goods, 1 and 2, and is a net exporter of good 1 and a net importer of good 2. Both goods are produced using CRS technology. Good 1 is produced in sector A using unskilled labor $\left(\mathrm{L}^{\mathrm{u}}\right)$ and sector specific land $(\mathrm{Z})$, and good 2 is produced in sector B using skilled labor $\left(\mathrm{L}^{\mathrm{S}}\right)$ and sector specific capital $(\mathrm{K})$. Skilled and unskilled workers are perfect substitutes in sector A. There is no substitution between skilled and unskilled workers in sector B. The amount of output produced by the import-competing sector $\left(\mathrm{X}^{2}\right)$ depends on the effort (e) of skilled workers. In order to get the required level of effort, the import-competing sector pays an efficiency wage $\left(\mathrm{w}^{\mathrm{S}}\right)$ to skilled workers employed. Output produced by 
the export sector $\left(\mathrm{X}^{1}\right)$ does not depend on a stipulated level of effort from unskilled workers and the unskilled wage rate $\left(\mathrm{w}^{\mathrm{u}}\right)$ is competitively determined. An exogenous export tax is in place. Let $\mathrm{t}$ be the export tax rate employed and let $\mathrm{p}^{*}$ be the relative world price of good 1.

The world price of good 2 is normalized to one. Equations (4.1) and (4.2) describe the production functions for goods 1 and 2 respectively:

$\mathrm{X}^{1}=\mathrm{X}^{1}\left(\mathrm{~L}^{\mathrm{u}}, \mathrm{Z}\right)$

$\mathrm{X}^{2}=\mathrm{X}^{2}(\mathrm{eL}, \mathrm{s})$

In order to determine the skilled wage rate, we assume for simplicity that the utility function for all workers is separable. The utility function is given by

$\mathrm{U}(\mathrm{w}, \mathrm{e})=\mathrm{v}(\mathrm{w})+\beta(\mathrm{e}), \mathrm{v}^{\prime}>0, \mathrm{v}^{\prime \prime}<0, \beta^{\prime}<0$

where $\mathrm{w}$ is the wage rate, $\mathrm{e}=\overline{\mathrm{e}}>0$ when employed in sector $\mathrm{B}$ and not shirking, $\mathrm{e}=\hat{\mathrm{e}}$ when shirking while employed in sector B, or when working in the export sector, and $\overline{\mathrm{e}}>\hat{\mathrm{e}}$. Let $\pi$ be the probability that a skilled worker is caught shirking at the beginning of the period, in which case he or she gets fired and must work as an unskilled worker in the export sector. For a skilled worker to provide effort, the expected utility from working must at least be equal to the expected utility from shirking:

$$
\left.\mathrm{v}\left(\mathrm{w}^{\mathrm{s}}\right)+\beta(\overline{\mathrm{e}}) \geq \pi\left(\mathrm{v}^{\mathrm{u}} \mathrm{w}^{\mathrm{u}}\right)+\beta(\hat{\mathrm{e}})\right)+(1-\pi)\left(\mathrm{v}\left(\mathrm{w}^{\mathrm{s}}\right)+\beta(\hat{\mathrm{e}})\right)
$$


Condition (4.4) holds with equality when skilled workers are indifferent between shirking and not shirking. Let us assume that this is the case and that skilled workers choose not to shirk. We can then solve (4.4) to get the skilled wage:

$\mathrm{v}\left(\mathrm{w}^{\mathrm{s}}\right)=\mathrm{v}\left(\mathrm{w}^{\mathrm{u}}\right)+\frac{\beta(\hat{\mathrm{e}})-\beta(\overline{\mathrm{e}})}{\pi}$

(4.5) implicitly defines:

$\mathrm{w}=\mathrm{w}\left(\overline{\mathrm{e}}, \mathrm{w}^{\mathrm{u}}\right)$

From (4.3), $\beta(\hat{\mathrm{e}})-\beta(\overline{\mathrm{e}})>0$. Therefore equation (4.5) implies that $\mathrm{w}$ is set above its opportunity cost $\left(\mathrm{w}^{\mathrm{u}}\right)$. The basic proposition of the efficiency wage hypothesis is that employers offer an above equilibrium wage rate to get the required level of effort. We proceed below to show that $\mathrm{w}$ is above the equilibrium wage rate. Firms in both sectors maximize profits. Equations (4.6) and (4.7) describe profit determination in sectors A and B respectively:

$\pi^{\mathrm{u}}=\mathrm{p}^{*}(1-\mathrm{t}) \mathrm{X}^{1}\left(\mathrm{~L}^{\mathrm{u}}, \mathrm{Z}\right)-\mathrm{w}^{\mathrm{u}} \mathrm{L}^{\mathrm{u}}-\mathrm{r}^{\mathrm{u}} \mathrm{Z}$

$\pi^{\mathrm{s}}=\mathrm{X}^{2}(\overline{\mathrm{e}} \mathrm{L}, \mathrm{s}, \mathrm{K})-\mathrm{w}{ }^{\mathrm{s}} \mathrm{s}-\mathrm{r} \mathrm{S}^{\mathrm{s}}$

From (4.6) and (4.7), the first order conditions for profit maximization with respect to the choice of labor yield:

$p^{*}(1-t) \frac{\partial X^{1}}{\partial L^{u}}\left(L^{u}, Z\right)=w^{u}$ 
$\frac{\partial X^{2}}{\partial L^{s}}\left(\bar{e} L^{s}, K\right) \bar{e}=w$

(4.8) and (4.9) implicitly define:

$\mathrm{L}^{\mathrm{u}}=\mathrm{L}^{\mathrm{u}}\left(\mathrm{p}^{*}(1-\mathrm{t}), \mathrm{Z}, \mathrm{w}^{\mathrm{u}}\right)$

$\mathrm{L}^{\mathrm{S}}=\mathrm{L}^{\mathrm{S}}\left(\overline{\mathrm{e}}, \mathrm{K}, \mathrm{w}^{\mathrm{S}}\right)$

Let ${ }^{-} \mathrm{u}$ and $\mathrm{L}^{-\mathrm{S}}$ be the available pool of unskilled and skilled workers. Suppose the export sector employs only unskilled labor. Equation (4.8) can then be solved for the marketclearing unskilled wage rate $\left(\mathrm{w}_{\mathrm{u}}^{*}\right)$ to yield:

$\mathrm{w}_{\mathrm{u}}^{*}=\mathrm{p}^{*}(1-\mathrm{t}) \frac{\partial \mathrm{X}^{1}}{\partial \mathrm{L}^{\mathrm{u}}}\left(\mathrm{L}^{-\mathrm{u}}, \mathrm{Z}\right)$

If the skilled labor market is allowed to clear, equation (4.9) can be solved for the marketclearing skilled wage $\left(\mathrm{w}_{\mathrm{S}}^{*}\right)$ to yield:

$\mathrm{w}_{\mathrm{s}}^{*}=\frac{\partial \mathrm{X}^{2}}{\partial \mathrm{L}^{\mathrm{s}}}\left(\overline{\mathrm{e}} \overline{\mathrm{L}}^{-\mathrm{s}}, \mathrm{K}\right) \overline{\mathrm{e}}$

There are two possible labor market outcomes, (i) and (ii) as discussed below: 


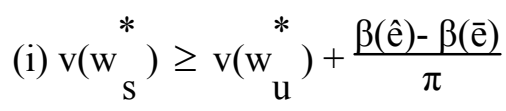

(ii) $\mathrm{v}\left(\mathrm{w}_{\mathrm{s}}^{*}\right)<\mathrm{v}\left(\mathrm{w}_{\mathrm{u}}^{*}\right)+\frac{\beta(\hat{\mathrm{e}})-\beta(\overline{\mathrm{e}})}{\pi}$

For the first outcome, no efficiency wage is required. The incentive is to work in sector B. The second outcome implies that at $\mathrm{w}^{\mathrm{s}}=\mathrm{w}_{\mathrm{S}}{ }_{\mathrm{S}}$, there is no incentive at all to work in sector B. Faced with this scenario, it follows that skilled workers will be attracted to sector B only if the following labor market outcome obtains:

(iii) $\mathrm{v}\left(\mathrm{w}^{\mathrm{s}}\right) \geq \mathrm{v}\left(\mathrm{w}_{\mathrm{u}}^{*}\right)+\frac{\beta(\hat{\mathrm{e}})-\beta(\overline{\mathrm{e}})}{\pi}$

(ii) and (iii) imply that $\mathrm{v}\left(\mathrm{w}^{\mathrm{S}}\right)>\mathrm{v}\left(\mathrm{w}_{\mathrm{S}}^{*}\right)$ and thus $\mathrm{w}^{\mathrm{S}}>\mathrm{w}_{\mathrm{S}}^{*}$, which shows that in equilibrium, the efficiency wage rate is set above the market-clearing wage rate. As a result, there is underemployment since the rationing of jobs in the import-competing sector means that part of the skilled labor force is forced to work as unskilled labor in the export sector. The increased labor supply in the export sector means $\mathrm{w}^{\mathrm{u}}<\mathrm{w}_{\mathrm{u}}^{*}$. Consequently final equilibrium is such that $\mathrm{w}^{\mathrm{S}}>\mathrm{w}_{\mathrm{S}}{ }^{*}>\mathrm{w}_{\mathrm{u}}{ }^{*}>\mathrm{w}^{\mathrm{u}}$ (see (4.5) and (iii)) and demand-supply equalization in the unskilled labor market is characterized by condition (4.10) below: 
$\mathrm{L}^{\mathrm{u}}\left(\mathrm{p}^{*}(1-\mathrm{t}), \mathrm{w}^{\mathrm{u}}\right)=\overline{\mathrm{L}}^{-\mathrm{u}}+\overline{\mathrm{L}}^{-\mathrm{s}}-\mathrm{L}^{\mathrm{s}}\left(\mathrm{w}^{\mathrm{s}}\left(\overline{\mathrm{e}}, \mathrm{w}^{\mathrm{u}}\right)\right)$

(4.10) implicitly defines:

$w^{u}=w^{u}\left(p^{*}(1-t), \bar{e}\right)$

If all wages were flexible, there would be no underemployment of skilled workers and trade liberalization would unambiguously improve welfare. The flexibility of both skilled and unskilled real wages would lead to efficient labor markets and the following expenditure-revenue identity: ${ }^{29}$

$\mathrm{E}\left(\mathrm{p}^{*}(1-\mathrm{t}), 1, \mathrm{U}\right)=\mathrm{R}\left(\mathrm{p}^{*}(1-\mathrm{t}), 1, \mathrm{~L}^{-\mathrm{u}}, \mathrm{L}^{-\mathrm{S}}\right)+\mathrm{tp} *\left(\mathrm{R}_{1}-\mathrm{E}_{1}\right)$

Differentiating (4.11), we have:

$\mathrm{E}_{\mathrm{u}} \mathrm{dU}=\mathrm{R}_{3} \mathrm{dL}-\mathrm{u}+\mathrm{R}_{4} \mathrm{~d} \mathrm{~L}^{-\mathrm{S}}-\mathrm{t}\left(\mathrm{p}^{*}\right)^{2}\left(\mathrm{R}_{11}-\mathrm{E}_{11}\right) \mathrm{dt}$

Concavity of the revenue function implies that $\mathrm{R}_{11}>0$, convexity of the expenditure function implies that $\mathrm{E}_{11}<0$ and $\mathrm{E}_{\mathrm{u}}>0$. Therefore the effect of an export tax reduction on welfare is negative as shown in $(4.11 \mathrm{~b})$.

$\frac{\mathrm{dU}}{\mathrm{dt}}=-\left(1 / \mathrm{E}_{\mathrm{u}}\right) \mathrm{t}\left(\mathrm{p}^{*}\right)^{2}\left(\mathrm{R}_{11}-\mathrm{E}_{11}\right)<0$

\footnotetext{
${ }^{29} \mathrm{We}$ summarize the main results. Detailed derivations can be found in the attached technical appendix. We will sometimes use the convention that for any function $f, f_{i}$ is the partial derivative of $f$ with respect to the $i^{\text {th }}$ argument. Similarly $f_{i j}$ is the partial derivative of the function $f_{i}$ with respect to the $j^{\text {th }}$ argument.
} 
Thus, trade liberalization improves welfare. The elimination of distortionary tax effects and efficiency gains from labor market flexibility lead to the welfare improvement. In the model with efficiency wages, two propositions can be derived.

\section{Proposition 1:}

Given the structure of employment described above, trade liberalization in the presence of endogenous underemployment leads to higher underemployment.

\section{Proof and comments:}

Assume that (i) and (ii) are satisfied so that there is some preexisting endogenous underemployment in the economy.

Totally differentiating (4.9a) and using (4.5a) and (4.10a):

$\mathrm{d} \mathrm{L}^{\mathrm{S}}=\gamma \mathrm{d} \overline{\mathrm{e}}+\frac{\partial \mathrm{L}^{\mathrm{S}}}{\partial \mathrm{K}} \mathrm{dK}+\delta \mathrm{dP}$

Where:

$$
\begin{aligned}
& \gamma=\frac{\partial \mathrm{L}^{\mathrm{s}}}{\partial \overline{\mathrm{e}}}+\frac{\partial \mathrm{L}^{\mathrm{s}}}{\partial \mathrm{w}}\left(\frac{\partial \mathrm{w}^{\mathrm{s}}}{\partial \mathrm{w}^{\mathrm{u}}} \frac{\partial \mathrm{w}^{\mathrm{u}}}{\partial \overline{\mathrm{e}}}+\frac{\partial \mathrm{w}^{\mathrm{s}}}{\partial \overline{\mathrm{e}}}\right) \\
& \delta=\frac{\partial \mathrm{L}}{\partial \mathrm{w}} \frac{\partial \mathrm{w}^{\mathrm{s}}}{\partial \mathrm{w}^{\mathrm{u}}} \frac{\partial \mathrm{w}^{\mathrm{u}}}{\partial \mathrm{P}}<0
\end{aligned}
$$

$P=p^{*}(1-t)$ 
Using relation (4.12a), the effect of trade liberalization on the demand for skilled labor is given by:

$\frac{\mathrm{dL}^{\mathrm{S}}}{\mathrm{dt}}=\delta \frac{\mathrm{dP}}{\mathrm{dt}}>0$

From (4.12e), a reduction in trade taxes reduces the demand for skilled workers in the import-competing sector. This is caused by sectoral adjustments as the economy shifts from import-competing production to export-oriented production. The export sector will therefore absorb skilled workers who are unable to find jobs in the import-competing sector and this gives rise to greater underemployment.

\section{Proposition 2:}

Trade liberalization has an ambiguous effect on welfare in the presence of endogenous underemployment. Free trade is not optimal and a small export tax leads to a welfare improvement.

\section{Proof and comments:}

Assume (i) and (ii) are satisfied so that endogenous underemployment exits. Labor allocation is not efficient and balanced international trade implies:

$E\left(p *(1-t), 1, U^{A}\right)=p * X^{1}+X^{2}-t^{*} E_{1}$

Totally differentiating (4.13) yields:

$\left(\mathrm{E}_{\mathrm{u}}+\mathrm{tp}^{*} \mathrm{E}_{1 \mathrm{u}}\right) \mathrm{dU}=\mathrm{p}^{*} \mathrm{~d} \mathrm{X}^{1}+\mathrm{d} \mathrm{X}^{2}+\mathrm{t}\left(\mathrm{p}^{*}\right)^{2} \mathrm{E}_{11} \mathrm{dt}$ 
Using (4.1), (4.2), (4.8), (4.9), and (4.10), the change in total revenue can be expressed as follows:

$\mathrm{p}^{*} \mathrm{~d} \mathrm{X}^{1}+\mathrm{dX}^{2}=\mathrm{p}^{*}\left(1-\frac{\mathrm{w}+\mathrm{tw}}{\mathrm{w}}\right) \mathrm{d} \mathrm{X}^{1}, \quad \frac{\mathrm{w}^{\mathrm{s}}+\mathrm{tw}}{\mathrm{w}}>1$

Using (4.13a) and (4.14) we have:

$\psi \frac{\mathrm{dU}}{\mathrm{dt}}=\mathrm{p}^{*}\left(1-\frac{\mathrm{w}^{\mathrm{s}}+\mathrm{tw}}{\mathrm{w}}\right) \frac{\mathrm{d} \mathrm{X}^{1}}{\mathrm{dt}}+\mathrm{t}\left(\mathrm{p}^{*}\right)^{2} \mathrm{E}_{11}$

$\psi=\mathrm{E}_{\mathrm{u}}+\mathrm{tp}^{*} \mathrm{E}_{1 \mathrm{u}}>0$

The effect of an export tax reduction on sector-1 can be shown to be negative:

$\frac{\mathrm{d} \mathrm{X}^{1}}{\mathrm{dt}}=\frac{\mathrm{w}^{\mathrm{u}}}{\mathrm{p}^{*}(1-\mathrm{t})} \frac{\left(\partial \mathrm{L}^{\mathrm{u}} / \partial \mathrm{t}\right)\left(\partial \mathrm{L}^{\mathrm{s}} / \partial \mathrm{w}{ }^{\mathrm{s}}\right)\left(\partial \mathrm{w} / \partial \mathrm{w}^{\mathrm{u}}\right)}{\partial \mathrm{L}^{\mathrm{u}} / \partial \mathrm{w}^{\mathrm{u}}+\left(\partial \mathrm{L}^{\mathrm{s}} / \partial \mathrm{w}^{\mathrm{s}}\right)\left(\partial \mathrm{w} / \partial \mathrm{w}^{\mathrm{u}}\right)}<0$

(4.14), (4.15a) and (4.15b) imply that $\frac{\mathrm{dU}}{\mathrm{dt}}$ has an ambiguous sign. Therefore trade liberalization has an ambiguous effect on welfare. There are two reasons why this is the case. First, the decrease in consumption and production distortions that occurs when the export tax is reduced improves welfare. Second, part of the skilled labor force is allocated to the unskilled sector and is therefore underemployed. This underutilization of some skilled workers represents an inefficient outcome which leads to a welfare loss. As a 
result, the net effect on welfare is unclear. However, if the effect of trade liberalization on welfare is evaluated at $t=0$, the result is unambiguous as shown below:

$\left.\frac{\mathrm{dU}}{\mathrm{dt}}\right|_{\mathrm{t}=0}=\left(1 / \mathrm{E}_{\mathrm{u}}\right) \mathrm{p}^{*}\left(1-\frac{\mathrm{w}+\mathrm{t} \mathrm{w}^{\mathrm{s}}}{\mathrm{u}}\right) \frac{\mathrm{dX}}{\mathrm{w}}>0$

This suggests that a small departure from free trade leads to a welfare improvement. At $\mathrm{t}=0$, all trade distortions have been eliminated. However a production distortion induced by efficiency wages is still present. A small tax corrects this efficiency wage distortion by expanding sector B relative to sector A. As sector B expands, it draws labor from sector $\mathrm{A}$ and this leads to a fall in underemployment. Welfare increases as a result of the efficiency gains from improved labor allocation. There is thus an optimal export tax $\left(\mathrm{t}^{*}\right)$ that maximizes welfare. The optimal tax is where $\psi \frac{\mathrm{dU}}{\mathrm{dt}}=0$, which can be obtained from (4.15):

$\mathrm{t}^{*}=-\left[\left(1-\frac{\mathrm{w}}{\mathrm{w}}\right) \frac{\mathrm{dX}}{\mathrm{dt}}\right] /\left[\frac{\mathrm{w}}{\mathrm{w}} \frac{\mathrm{dX}}{\mathrm{w}} \frac{1}{\mathrm{dt}}+\mathrm{p}^{*} \mathrm{E}_{11}\right]>0$

Thus, partial trade liberalization is optimal for a small open economy with underemployment.

\subsection{Model specification and data description}

Proposition 1 can be analyzed empirically using relation (4.9a). Based on this relation, we can specify the following equation:

$\mathrm{L}=\alpha_{0}+\alpha_{1} \overline{\mathrm{e}}+\alpha_{2} \mathrm{~K}+\alpha_{3} \mathrm{w}+\mathrm{u}_{1}$ 
Using relations (4.5a) and (4.10a), we can specify the following equations:

$\mathrm{w}=\beta_{0}+\beta_{1} \overline{\mathrm{e}}+\beta_{2} \mathrm{w}^{\mathrm{u}}+\mathrm{u}_{2}$

$\mathrm{w}^{\mathrm{u}}=\theta_{0}+\theta_{1} \mathrm{p}^{*}+\theta_{2} \mathrm{t}+\theta_{3} \overline{\mathrm{e}}+\mathrm{u}_{3}$

Substituting (4.18) and (4.19) into (4.17) we get the following reduced form equation for skilled labor demand:

$\mathrm{L}^{\mathrm{S}}=\lambda_{0}+\lambda_{1} \overline{\mathrm{e}}+\lambda_{2} \mathrm{~K}+\lambda_{3} \mathrm{p}^{*}+\lambda_{4} \mathrm{t}+\mathrm{u}_{4}$

The expected effects of $\overline{\mathrm{e}}, \mathrm{p}^{*}$ and $\mathrm{K}$ on $\mathrm{L}^{\mathrm{S}}$ can be analyzed using relation (4.12a).

Differentiating $\mathrm{L}^{\mathrm{S}}$ with respect to ē yields:

$\frac{\mathrm{dL}^{\mathrm{s}}}{\mathrm{de}}=\gamma$

Relation (4.20a) has an ambiguous sign. However, since productivity is the basis upon which labor is hired, we expect the partial effect of $\overline{\mathrm{e}}$ on $\mathrm{L}^{\mathrm{S}}$ to dominate, so that overall $\frac{\mathrm{dL}^{\mathrm{S}}}{\mathrm{de}}$ has a positive sign. Differentiating $\mathrm{L}^{\mathrm{s}}$ with respect to $\mathrm{p}^{*}$ yields:

$\frac{\mathrm{dL}^{\mathrm{S}}}{\mathrm{dp}^{*}}=\delta(1-\mathrm{t})<0$

Relation (4.20b) implies that an improvement in the terms of trade reduces the demand for skilled labor. This is the expected result. An improvement in the terms of trade expands the export sector. As the export sector expands, labor is reallocated from the import-competing sector to the export sector. Differentiating $\mathrm{L}^{\mathrm{s}}$ with respect to K yields:

$$
\frac{\mathrm{dL}^{\mathrm{s}}}{\mathrm{dK}}=\frac{\partial \mathrm{L}^{\mathrm{s}}}{\partial \mathrm{K}}>0
$$


As expected, relation (4.20c) shows that a rise in the capital stock increases demand for skilled employment. We already know from proposition 1 that trade liberalization is expected to reduce the demand for skilled workers.

Employment in the industrial sector as a percent of total employment is used to measure the skilled workforce. Value added per person employed in the manufacturing sector measures labor productivity. Export prices are measured using the terms of trade. Trade taxes are measured using average tariff rates (t) ${ }^{30}$ Gross capital formation (GCF) as a percent of GDP is used to measure K. Data on industry employment and labor productivity were obtained from the ILO-Key Indicators of the Labor Market (2002). Terms of trade data are from the World Bank's Global Development Network Growth Dataset and average tariff rates were obtained from the World Bank's International Trade and Development dataset. Data on gross capita formation was obtained from the World Bank's World Development Indicators (2002).

Additional data on government final consumption expenditure as a percent of GDP (gov) and secondary school gross enrollment ratios (sch) were also obtained from the World Bank's World Development Indicators (2002) and are used to carry out robustness checks. As in Savvides (1995), we use secondary school enrollment ratios as a measure of investment in human capital and government consumption expenditure as a measure of fiscal policy. Policy misdirection is one of the reasons why developing countries have experienced poor economic performance. We therefore expect the variable gov to be negatively related with skilled employment. Investment in human capital is expected to raise the skill level and thereby increase employment opportunities.

\footnotetext{
${ }^{30}$ Data on export taxes was unavailable. However, by virtue of the Lerner symmetry we know that export taxes and tariffs have analogous effects.
} 
The variable sch should therefore be positively related with skilled employment. Data for all the variables is available for 19 developing economies for the period 1990-1999. ${ }^{31}$

\subsection{Model estimation and empirical results}

Equation (4.20) is estimated by OLS in non-linear form (using logs) for the 19 countries. ${ }^{32}$ To account for country effects, panel data estimation with one-way fixed effects is used. ${ }^{33}$ It is possible that tariffs may be influenced by employment. To avoid the problem of endogeneity bias, we use lagged $t$ as an instrument for $t$. The correlation between $\mathrm{t}$ and $\mathrm{t}$ lagged is 0.99 and the correlation between $\mathrm{t}$ lagged and the residuals is 0.29. These correlations suggest that $t$ lagged has the desirable properties of a good instrument. The results of the estimation are reported in table 4.1. An increase in productivity leads to higher skilled employment as expected. The result is significant. A rise in the capital stock increases demand for skilled employment. The result is however not significant. Terms of trade improvements significantly increase skilled employment. This result differs from what the model predicts. A reduction in tariffs causes a significant decline in skilled employment as predicted by the theoretical analysis.

Two robustness checks are conducted. We check whether the results are robust to the addition of other exogenous variables. In addition, we also check whether the results are robust to country selection. We augment equation (4.20) by adding gov and sch :

$$
\mathrm{L}^{\mathrm{S}}=\lambda_{0}+\lambda_{1} \overline{\mathrm{e}}+\lambda_{2} \mathrm{~K}+\lambda_{3} \mathrm{p}^{*}+\lambda_{4} \mathrm{t}+\lambda_{5} \text { gov }+\lambda_{6} \mathrm{sch}+\mathrm{u}_{5}
$$

\footnotetext{
31 The developing countries are China, Hong Kong, South Korea, Taiwan, India, Pakistan, Sri Lanka, Indonesia, Malaysia, Phillipines, Singapore, Thailand, Argentina, Brazil, Chile, Colombia, Mexico, Peru, and Venezuela.

${ }^{32}$ We use logs because of non-linear dependencies in the data.

${ }^{33}$ With such a short sample for each country, the one-way fixed effects model is more reliable than the twoway fixed effects model.
} 
Non-linear estimation of equation (4.21) yields the results reported in table 4.2. The results are robust and significant. A sound fiscal policy significantly contributes to higher skilled employment as expected. Increasing investment in human capital raises skilled employment as expected. The correlation matrix of exogenous variables is shown in table 4.3. The correlation structure shows that multicollinarity is not a problem. Finally we check the sensitivity of the results to country selection. We find that excluding any one country from the estimation does not overturn the results. ${ }^{34}$

To summarize, the empirical results show that reducing import tariffs causes a significant decrease in skilled employment. This result does not change when different robustness checks are conducted. In the context of the theoretical model, the skilled workers who have lost their jobs in the skilled sector will be reallocated to the unskilled sector where they will be underemployment. Viewed from the perspective of the theoretical model, the empirical results lend strong support to proposition $1 .{ }^{35}$

\subsection{Summary and conclusions}

The chapter develops a two sector general equilibrium model that explicitly takes into account the employment structure and wage inflexibility of a typical small open economy. Real wage rigidity in the skilled sector results in underemployment. The model is used to analyze how trade liberalization affects underemployment and welfare. We find that liberalizing trade by reducing export taxes expands the unskilled sector and contracts the skilled sector. These sectoral shifts lead to greater underemployment.

Our results also show that liberalizing trade by reducing export taxes has an ambiguous effect on welfare due to the presence of endogenous underemployment. In

\footnotetext{
${ }^{34}$ The results for sensitivity to country selection are not reported, but are available upon request.

${ }^{35}$ The direct effect of trade liberalization on underemployment could not be estimated due to lack of data.
} 
fact, free trade is not optimal: we find that a small export tax leads to a welfare improvement. The reason is that a small tax reduces underemployment by expanding the skilled sector relative to the unskilled sector. Welfare increases as a result of the efficiency gains from improved labor allocation.

We complement the theoretical analysis with an empirical analysis of the effect of trade liberalization on underemployment. This is done by estimating a regression model with fixed effects for a panel of 19 developing economies. The empirical results show that trade liberalization significantly reduces employment in the skilled sector as predicted by the theoretical model. Robustness checks give the same result. This result provides indirect evidence that trade liberalization increases underemployment as explained by the theoretical model.

The analysis leads us to conclude that there is a conflict between trade liberalization, underemployment and welfare. This conflict arises from a failure to address the structure and functioning of labor markets in small open economies. 
Table 4.1: Estimation results

(Dependent variable $=$ skilled labor demand $\left.\left(L^{S}\right)\right)$

\begin{tabular}{ccc}
\hline Explanatory Variable & Coefficient & P-value \\
Labor productivity $(\overline{\mathrm{e}})$ & .126 & .0469 \\
Capital stock $(\mathrm{K})$ & $(2.002)$ & .2814 \\
& $.455 \mathrm{E}-01$ & \\
Terms of trade $\left(\mathrm{p}^{*}\right)$ & $(1.081)$ & .0000 \\
& .475 & .0022 \\
Import tariffs $(\mathrm{t})$ & $(6.622)$ & \\
\hline
\end{tabular}

t-statistics in parenthesis.

Table 4.2: Estimation results with additional exogenous variables $\left(\right.$ Dependent variable $=$ skilled labor demand $\left.\left(L^{S}\right)\right)$

\begin{tabular}{ccc}
\hline Explanatory Variable & Estimated Coefficient & P-value \\
Labor productivity $(\overline{\mathrm{e}})$ & .170 & .0248 \\
& $(2.270)$ & .1586 \\
Capital stock $(\mathrm{K})$ & $.920 \mathrm{E}-01$ & \\
& $(1.418)$ & .0038 \\
Terms of trade $\left(\mathrm{p}^{*}\right)$ & .299 & .0009 \\
& $(2.946)$ & \\
Import tariffs $(\mathrm{t})$ & .119 & .0077 \\
& $(3.410)$ & \\
Fiscal policy $(\mathrm{gov})$ & -.107 & .0198 \\
& $(-2.706)$ & \\
\hline
\end{tabular}

t-statistics in parenthesis 


\section{CHAPTER 5}

\section{Summary, Conclusions and Directions of Future Research}

\subsection{Summary and conclusions of the dissertation}

This dissertation provides an analysis of the effect of transfers and trade policy on the welfare of developing countries. The effects of transfers and trade policy have been studied since World War I, and the literature has established that transfers affect welfare though income and prices effects. The income effect represents the transfer of purchasing power and is welfare enhancing. On the other hand, the price effect represents the induced change in the terms of trade and reduces welfare under certain conditions. If the price effect dominates, the recipient of a transfer suffers a net welfare loss. The possible occurrence of such a transfer paradox has been widely analyzed in the literature.

The effect of trade policy on welfare has also received a lot of attention in the literature. There is strong evidence in the literature which shows that open trade regimes improve welfare by eliminating distortions and expanding employment opportunities. As a result, developing countries have been urged to pursue trade liberalization reforms by lowering trade barriers. The literature has however not focused on how transfers and trade policy interact with structural factors to deliver welfare outcomes. The welfare of developing countries is affected by structural factors such as import dependency and underemployment.

Production and investment in low income developing countries are highly dependent on imported capital goods. The imported capital goods are used in the import competing industrialized sector. The exporting sector focuses on primary products where land and labor are predominantly used. Growth and thus welfare depends on these 
imports. In addition, underemployment rather than unemployment is the fundamental problem in developing countries. Trade policy reform in developing countries seeks to improve welfare by expanding labor intensive employment. The employment gains from such reform will be very small in the presence of high underemployment. What really matters from a welfare point of view is how trade policy affects underemployment. The need to factor these two structural factors in the analysis of the effect of transfers and trade policy on the welfare of developing countries provided the motivation for conducting this research.

In chapter 2, we build a two-good general equilibrium model, which takes into account the use of foreign capital in the import competing sector and the use of land in the exporting sector producing mainly primary products. Labor is used in both sectors. The model is used to theoretically analyze how financial transfers and capital transfers to a developing country affect the welfare of the developing country. In addition, we also analyze the welfare effect of financial transfers using simulations.

In the case of transfers of financial aid, we find that such transfers induce changes in commodity terms of trade, which in turn affects capital inflows and the price of imported capital. If export taxes are taken to be exogenous, we find that endogenous capital flows aggravate the transfer problem that exists under trade taxation. When trade liberalization is tied to transfers, we find that the tying of aid may worsen or alleviate the transfer problem, depending on how the existing export tax compares with the optimum. To shed more light on the transfer problem in the context of trade liberalization tied to transfers, we solve the model numerically and conduct simulations. We find that the 
tying of aid results in a welfare loss for the recipient nation, given the functional forms and parameter values used in carrying out the simulations.

In the case of capital transfers, we find that such transfers affect welfare through a price effect, a production effect and an income effect. The presence of a trade distortion causes the price effect and production effect to overcome the income effect. As a result, the recipient suffers a net welfare loss. The recipient's welfare falls despite the fact that productive capacity and hence growth has been increased by the transfer of capital. Growth is therefore immiserizing.

In conclusion, transfer paradoxes cannot be ruled out in the context of capital goods. If there is a trade distortion, untied transfers reduce welfare through a value effect (higher price of imported capital) and a volume effect (greater inflow of capital). Both the value effect and the volume effect are induced by the price effect of the transfer. The tying of financial transfers can also lead to a welfare loss. Capital transfers may reduce welfare by causing immiserizing growth.

Chapter 3 builds an econometric model and empirically analyzes the transfer problem in the presence of an exogenous export tax and endogenous capital inflows. This is done by estimating a regression model with fixed effects for a panel of 14 countries in SSA. Our empirical results show that multilateral transfers significantly reduce terms of trade. The reduction in terms of trade significantly induces foreign capital inflows. Increased capital inflows and terms of trade deterioration significantly offset the real GDP gains from multilateral transfers. The results are consistent with the theoretical analysis in chapter 2 and are robust. 
To conclude, our results suggest that an additional factor may be relevant in explaining why SSA's welfare failed to improve. In the presence of capital imports, the price effect leads to a volume effect (greater inflow of capital). Both the price effect and the volume effect offset the income effect. Consequently overall welfare will fall if the income effect is dominated by the other two effects.

In chapter 4 , we develop a two sector general equilibrium model that explicitly takes into account the employment structure and wage inflexibility of a typical small open economy. Real wage rigidity in the skilled sector results in underemployment. The model is used to analyze how trade liberalization affects underemployment and welfare. We find that liberalizing trade by reducing export taxes expands the unskilled sector and contracts the skilled sector. These sectoral shifts lead to greater underemployment. The results also show that liberalizing trade by reducing export taxes has an ambiguous effect on welfare due to the presence of endogenous underemployment. In fact, free trade is not optimal: we find that a small export tax leads to a welfare improvement. The reason is that a small tax reduces underemployment by expanding the skilled sector relative to the unskilled sector. Welfare increases as a result of the efficiency gains from improved labor allocation.

We complement the theoretical analysis with an empirical analysis of the effect of trade liberalization on underemployment. This is done by estimating a regression model with fixed effects for a panel of 19 developing economies. The empirical results show that trade liberalization significantly reduces employment in the skilled sector as predicted by the theoretical model. Robustness checks give the same result. This result 
provides indirect evidence that trade liberalization increases underemployment as explained by the theoretical model.

The analysis leads us to conclude that there is a conflict between trade liberalization, underemployment and welfare. This conflict arises from a failure to address the structure and functioning of labor markets in small open economies.

\subsection{Directions of future research}

In this dissertation we highlighted the importance of policy mistakes in contributing to SSA's lack of welfare improvement. It was also noted that inappropriate forms of transfers may have contributed to the failure of economic reforms to deliver positive welfare outcomes. Our future research will examine these two issues in relation to the transfer problem. More specifically, we plan to analyze the effect of multilateral transfers on policies. The extent to which transfers change policies is useful for welfare analysis.

Instead of using aggregated data on EDA in the welfare analysis, it may be more useful to analyze welfare using the more disaggregated data. This will yield information on the forms taken by EDA such as project aid, import support, and debt relief. We will also be able to tell which form of aid is tied or untied. By analyzing the effect of different forms of aid on welfare, we can find out the forms of transfers better suited to improving welfare. In addition, our future research will analyze the effect of bilateral transfers on the welfare of developing countries. This will enable us to compare the welfare effects of multilateral transfers and bilateral transfers. An analysis of the 
determinants of these transfers will also be carried out. Such an analysis will contribute to a better understanding of the welfare effects of transfers.

As regards trade liberalization and underemployment, our future research will analyze the effect of other border measures of trade barriers such as quotas and border delays on skilled employment. In addition, it would be interesting to analyze the effect of "inside the border" measures of trade barriers such as attitudes towards trade and identities. In the literature, it has been shown that attitudes towards trade are significantly correlated with human capital. It has also been shown in the literature that high identities in the form of high nationalism or patriotism lead to protectionist policies. ${ }^{36}$ We will then be able to assess the effectiveness of border measures vs. "inside the border" measures in reducing underemployment. Finally, since unemployment is the most widely used indicator to assess labor market developments as well as economic performance, we plan to incorporate this variable in future analysis.

\footnotetext{
${ }^{36}$ See for example Mayda and Rodrik (2001). Data on these measures is available from the International Social Survey Programme dataset.
} 


\section{References}

Arkelof, George A, "Labor Contracts as Partial Gift Exchange," Quarterly Journal of Economics, 97, 1982, 543-69.

Arkelof, George A, and Yellen Janet L, "Efficiency Wage Models of the Labor Market," Cambridge: Cambridge University Press, 1986.

Agenor, P., "The Labor Market and Economic Adjustment," IMF Staff Papers, 43, 1996, 261-335.

Bandyopadhyay, S and Majumdar, B, 2003, "Multilateral Transfers, Export Taxation and Asymmetry," Journal of Development Economics, forthcoming.

Balassa, Bela, Development Strategies in Semi-Industrial Economies, NY and London: Oxford U. Press, 1982.

Bhagwati, Jagdish N, Brecher, Richard A and Hatta, Tatsuo, 1983, "The Generalized Theory of Transfers and Welfare: Bilateral Transfers in a Multilateral World," American Economic Review, 73, 606-618.

Barro, R.J., 2000, “Inequality and Growth in a Panel of Countries," Journal of Economic Growth, March, 5-32.

Brakeman, S and van Marrewijk, C., "The Economics of International Transfers," Cambridge: Cambridge University Press, 1998.

Brecher, R.A and Bhagwati, J.N., 1982, "Immiserizing Transfers from Abroad," Journal of International Economics, 13, 353-364.

Burnside, C and Dollar, D., "Aid, Policies, and Growth," American Economic Review, 90:4, 2000, 847-68.

Bush, George W., Speech delivered on March 14, 2002, available at: www.whitehouse.gov.

Chang, C and Fernandez-Arias L, and Serven L., 1998, "Measuring Aid Flows, A New Approach," World Bank Policy Research Working Paper 2050.

Collier, P and Dehn, J., “Aid, Shocks, and Growth,” working paper \#2688, 2001, World Bank.

Collier, P and Dollar, D., "Aid Allocation and Poverty Reduction," European Economic Review, 46, 2002, 1475-500. 
Collier, Paul, "The Marginalization of Africa," 1995, International Labor review, 134, 541-557.

Collier, Paul and Gunning, Jan Willem, 1999, "Why Has Africa Grown Slowly?" Journal of Economic Perspectives, 13, 3-22.

Corbo, V and Fischer, S., 1995, "Structural Adjustment, Stabilization and Policy Reform: Domestic and International Finance," in Handbook of Development Economics, Vol.III, Chapter 44, Elsevier Science, 1995.

Currie, J., and Harrison, A., "Trade Reform and Labor Market Adjustment in Morocco," Journal of Labor Economics, 1997.

Dalgaard, C and Hansen, H., "On Aid, Growth and Good Policies," Journal of Development Studies, 37, 2001, 17-41.

Davies, R., "Trade, Trade Management and Development in Zimbabwe," in Trade and Development in Sub-Saharan Africa, Manchester: Manchester University Press, 1991.

Davies, R., and Rattso, J., 1993, "Zimbabwe," in: L. Taylor, ed., The Rocky Road to Reform: Adjustment, Income Distribution and Growth in the Developing World, MIT Press, Cambridge, MA, 1993.

Eaton, J., 1989, "Foreign Public Capital Flows," in Handbook of Development Economics, Vol. II, Chapter 25, Elsevier Science, 1989.

Easterly, William, “Can Foreign Aid Buy Growth?” Journal of Economic Perspectives, $17,2003,23-48$.

Easterly, William and Levine Ross, 1997, “Africa's Growth Tragedy: Policies and Ethnic Divisions," Quarterly Journal of Economics, 112, 1203-1250.

Edwards, Sebastian, "Openness, Trade Liberalization, and Growth in Developing Countries," Journal of Economic Literature, Vol. 31, 1993, 1358-1393.

Frey, B., and Schneider, "Competing Models of International Lending Activity,"Journal of Development Economics, 20, 1986, 225-245.

Foster, James E and Henry, Wan Y, "Involuntary Unemployment as a Principal -Agent Equilibrium," American economic Review, 74, 1984, 476-84.

Forteza, A and Rama, M., "Labor Market Rigidity and the Success of Economic Reforms Across more than One Hundred Countries," working paper \#2521, World Bank, 2001. 
Gale, D., "Exchange Equilibrium and Coalitions: An Example," Journal of Mathematical Economics, 1, 1974, 63-66.

Greenaway and Milner, "Fiscal Dependency on Trade Taxes and Trade Policy Reform," Journal of Development Studies, 27, 95-132.

Ghai, D., "Successes and Failures in African Development: 1960-82," OECD Seminar on "Alternative Development Strategies," January 1987.

Green, William H, “Econometric Analysis," New Jersey: Prentice Hall, Inc, $4^{\text {th }}$ Edition, 2000 .

Green, Reginald H, and Kadhani, X., "Zimbabwe: Transition to Economic Crises, 19811983: Retrospect and Prospect," World Development, 14, 1986, 1059-1083.

Guillamont, P and Chauvet, L., "Aid and Performance: A Reassessment," Journal of Development Studies, 37, 66-92.

Hansen, H and Tarp, F., "Aid and Growth Regressions," Journal of Development Economics, 64, 2001, 547-70.

Hansen, H and Tarp, F., "Aid Effectiveness Disputed," Journal of International Development, 12, 2000, 375-98.

Harrison, Ann and Gordon, Hanson, "Who Gains from Trade Reform? Some Remaining Puzzles,” NBER working paper \# 6915, 1999.

Helleiner, G.K., (1992), "The IMF, The World Bank and Africa's Adjustment and External Debt Problems: An Unofficial View," World Development, 20, 1992,779-792.

Helleiner, G.K., "Structural Adjustment and Long-Term Development in Sub-Saharan Africa." Paper Presented at the Workshop on Alternative Development Strategies in Africa, Oxford, 1994.

Hsiao, C., “Analysis of Panel Data,” New York: Cambridge University Press, 1986.

ILO, “Key Indicators of the Labor Market 2001-2002,” New York: Routledge, 2002.

IMF Annual Report, 1996.

IMF, “World Economic Outlook,” International Monetary Fund, Washington DC, May 1993. 
Jones, Ronald W and Neary, Peter J., "The Positive Theory of International Trade," in Handbook of International Economics, Vol. I, Chapter 1, Elsevier Science, 1984.

Kemp, Murray C., "The Gains From Trade and the Gains from Aid," in Essays in International Trade Theory, New York: Routledge, 1995.

Kemp, Murray C, and Kojima, S., "Tied Aid and the Paradoxes of Donor Enrichment and Recipient-Impoverishment," International Economic Review, 26, 1985, 721-729.

Keynes, J.M., "The German Transfer Problem,” Economic Journal, 39, 1929a, 1-7.

"The Reparations Problem: A Discussion. II: A Rejoinder," Economic Journal, 39, 1929b, 179-82.

"Mr. Keynes' Views on the Transfer Problem. III: A Reply," Economic Journal, $39,1929 \mathrm{c}, 404-8$.

Knight, M., Loayza, N., and Villanueva, D., "Testing the Neoclassical Theory of Economic Growth: A Panel Data Approach," IMF Staff Papers, 40, 1993, 512541.

Knight, J. B, "Devaluation and Income Distribution in Less-Developed Economies," Oxford Economic Papers, 28, 1976, 208-227.

Krugman, Paul R, and Obstfeld Maurice, "International Economics: Theory and Policy," Addison-Wesley: $6^{\text {th }}$ Edition, 2003.

Krueger, A. O., Trade and Employment in Developing Countries, Chicago, University of Chicago Press, 1983.

Lensink, R and White, H., "Are there Negative Returns to Aid?" Journal of Development Studies, 37, 2001, 42-65.

Levy, V., "Aid and Growth in Sub-Saharan Africa: The Recent Experience," European Economic Review, 32,1988,1777-1795.

Lopez, R and Thomas, V., "Import Dependency and Structural Adjustment in SubSaharan Africa," World Bank Economic Review, 4, 1990, 195-207.

Mayda, N, and Rodrik, D., "Why are Some People (and Countries) more Protectionist than Others?" NBER working paper \#8461, 2001.

Michaely, M, Papageorgiou, D, Choksi,A., Liberalizing Foreign Trade, Vol. 7, Lessons of Experience in the Developing World, Oxford and Cambridge, MA: Basil Blackwell, 1991.

Mhone, G., "Enclavity and Constrained Labor Absorptive Capacity in Southern African Economies," ILO/SAMAT discussion paper no.12, 2000. 
Moran, C., "Imports under a Foreign Exchange Constraint," World Bank Economic Review, 3, 1989, 279-295.

Ndulu, B., "Investment, Output Growth and Capacity Utilization in an African Economy: The Case of Manufacturing Sector in Tanzania," Eastern Africa Economic Review, 2, 14-30.

Ndulu, B., "Foreign Resource Flows and the Financing of Development in Sub-Saharan Africa." Paper Presented at the G-24 Conference on the Fiftieth Anniversary of Bretton Woods Institutions, Colombia, 1994.

Ndulu, B., "Growth and Adjustment in Sub-Saharan Africa, in Economic Reform in SubSaharan Africa, Washington: World Bank, 1991.

Ohlin, B., "The Reparations Problem: A Discussion; Transfer Difficulties, Real and Imagined," Economic Journal, 39, 1929a, 172-83.

Mr. Keynes' Views on the Transfer Problem. II: A Rejoinder from Professor Ohlin, Economic Journal, 39, 1929b, 400-4.

Rattso, J., "Medium-run Adjustment Under Import Compression: Macroeconomic Analysis Relevant for Sub-Saharan Africa," Journal of Development Economics, 45, 1994, 35-54.

Revenga, A., "Employment and Wage Effects of Trade Liberalization: the Case of Mexican Manufacturing," paper prepared for World Bank Labor Markets Workshop, July 1997.

Rodrik, D., "Why is there Multilateral Lending?” NBER working paper \#5160, 1995.

Rodrik, Dani, “ Trade Policy and Economic Performance in Sub-Saharan Africa,” NBER Working Paper \# 6562, 1998.

Sachs, Jeffrey D and Warner Mark, "Sources of Slow Growth in African Economies," Journal of African Economies, 6, 1997, 335-76.

Sachs, Jeffrey D and Warner Andrew, "Economic Reform and the Process of Global Integration," Brookings Papers on Economic Activity, 1, 1995.

Samuelson, P. A., Foundations of Economic Analysis, Cambridge, Mass: Harvard University Press, 1947.

Savvides, A., "Economic Growth in Africa," World Development, 23, 1995,449-458.

Schweinberger, A. G., "On the Welfare Effects of Tied Aid," International Economic Review, 31, 1990, 457-462. 
Sender, J., "Africa's Economic Performance: Limitations of the Current Consensus," Journal of Economic Perspectives, 13, 1999, 89-114.

Shapiro, Carl and Stiglitz Joseph E, "Equilibrium Unemployment as a Worker Discipline Device", American Economic Review, 74, 1984, 433-44.

Stiglitz, Joseph E., "Towards a New Paradigm for Development," $9^{\text {th }}$ Prebisch Lecture Delivered at UNCTAD, Geneva, October 1998.

Thomas, V., "Developing Country Experience in Trade Reform," working paper \#295, World Bank.

Wangwe, Samuel M, "Industrialization and Resource Allocation in a Developing Country: The Case of Recent Experiences in Tanzania," World Development, 11, 1983, 483-492.

Weiss, Andrew, "Job Queues and Layoffs in Labor Markets with Flexible Wages," Journal of Political Economy, 88, 1980, 526-38.

Wheeler, D., "Sources of Stagnation in Sub-Saharan Africa," World Development, 12, 1984, 1-23.

Wolfensohn, J., Quoted in World Bank (2002).

World Bank, "A Case for Aid: Building a Consensus for Development Assistance," Washington, D.C., 2002.

World Bank, “ Sub-Saharan Africa-From Crisis to Sustainable Growth”, Washington, D.C, 1989.

World Bank, Accelerated Development in Sub-Saharan Africa: An Agenda for Action, Washington, DC, 1981.

World Bank, Adjustment in Africa, New York: Oxford University Press, 1994.

World Bank "Aid and Reform in Africa: Lessons from Ten Case Studies," Washington, DC, 2001.

World Bank, "Workers in an Intergrating World," World Development Report, World Bank, Washington, DC, 1995.

World Bank, Africa's Adjustment and Growth in the 1980s, Washington, DC, 1989.

Yeats, Alexander J., "Did Domestic Policies Marginalize Africa in World Trade," World Bank, Directions in Development series, Washington, DC, 1997. 


\section{Appendix I: Variables used and sources of data}

\begin{tabular}{|l|l|l|}
\hline Variable & Definition & Source of data \\
\hline $\mathrm{U}^{\mathrm{A}}$ & The change in real GDP of nation A. & WDI (World Bank, 2002) \\
\hline $\mathrm{K}^{\mathrm{I}}$ & Real imports of capital goods. & Ndulu (1991), WDI (2002) \\
\hline $\mathrm{p}$ & The terms of trade. & $\begin{array}{l}\text { GDNG dataset (World } \\
\text { Bank, 2002) }\end{array}$ \\
\hline $\mathrm{t}$ & Average tariff rate. & $\begin{array}{l}\text { Trade and import barriers } \\
\text { dataset (World Bank, 2003) }\end{array}$ \\
\hline $\mathrm{T}$ & Real multilateral aid. & $\begin{array}{l}\text { Chang, Fernandez-Arias, } \\
\text { and Serven (1998) }\end{array}$ \\
\hline imports & Real imports. & WDI (World Bank, 2002) \\
\hline GCF & Real gross capital formation. & WDI (World Bank, 2002) \\
\hline open & Trade as a percent of GDP. & WDI (World Bank, 2002) \\
\hline growth & GDP per capita growth (annual \%). & WDI (World Bank, 2002) \\
\hline inf & Inflation. & WDI (World Bank, 2002) \\
\hline $\mathrm{L}$ & $\begin{array}{l}\text { Employment in the industrial sector as a } \\
\text { percent of total employment. }\end{array}$ & KILM (ILO, 2002) \\
\hline$\overline{\mathrm{e}}$ & $\begin{array}{l}\text { Value added per person employed in the } \\
\text { manufacturing sector measures labor } \\
\text { productivity. }\end{array}$ & KILM (ILO, 2002) \\
\hline $\mathrm{K}$ & Gross capital formation as a percent of GDP. & WDI (World Bank, 2002) \\
\hline $\mathrm{p}^{*}$ & $\begin{array}{l}\text { The terms of trade. } \\
\text { gov }\end{array}$ & $\begin{array}{l}\text { Government final consumption expenditure as } \\
\text { a percent of GDP. } \\
\text { Bank, 2002) }\end{array}$ \\
\hline sch & Secondary school gross enrollment ratio. & WDI (World Bank, 2002) \\
\hline
\end{tabular}

KILM $=$ Key Indicators of the Labor Market

$\mathrm{WDI}=$ World Development Indicators

GDNG $=$ Global Development Network Growth 


\section{Appendix II: Political Geography of Africa}

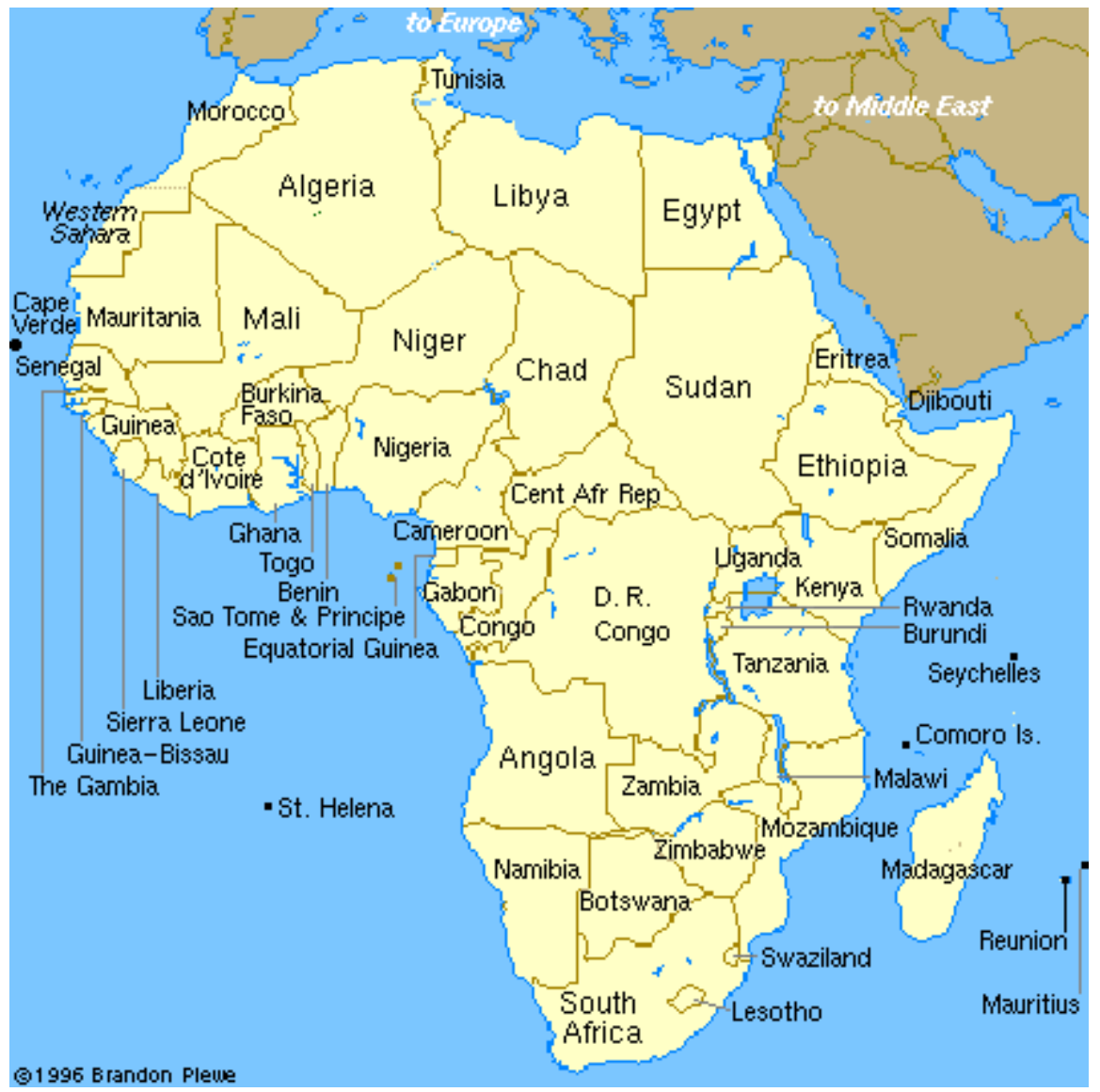




\title{
Appendix III: Multilateral Transfers to Sub-Saharan Africa
}

\section{(a) IDA Borrowers}

\author{
Angola \\ Benin \\ Burkina Faso \\ Burundi \\ Cameroon \\ Cape Verde \\ Central African Republic \\ Chad \\ Comoros \\ Congo, Dem. Rep. \\ Congo, Rep. \\ Côte d'Ivoire \\ Eritrea \\ Ethiopia \\ Gambia, The \\ Ghana \\ Guinea \\ Guinea-Bissau \\ Kenya \\ Lesotho \\ Liberia \\ Madagascar \\ Malawi \\ Mali \\ Mauritania \\ Mozambique \\ Niger \\ Nigeria \\ Rwanda \\ São Tomé and Principe \\ Senegal \\ Sierra Leone \\ Somalia \\ Sudan \\ Tanzania \\ Togo \\ Uganda \\ Zambia \\ Zimbabwe
}


(b) Countries in Sub-Saharan Africa Eligible for the IMF Poverty Reduction and Growth Facility (PRGF) as of September 2003

\author{
Angola \\ Benin \\ Burkina Faso \\ Burundi \\ Cameroon \\ Cape Verde \\ Central African Republic \\ Chad \\ Comoros \\ Congo, Dem. Rep. \\ Congo, Rep. \\ Côte d'Ivoire \\ Eritrea \\ Ethiopia \\ Gambia, The \\ Ghana \\ Guinea \\ Guinea-Bissau \\ Kenya \\ Lesotho \\ Liberia \\ Madagascar \\ Malawi \\ Mali \\ Mauritania \\ Mozambique \\ Niger \\ Nigeria \\ Rwanda \\ São Tomé and Principe \\ Senegal \\ Sierra Leone \\ Somalia \\ Sudan \\ Tanzania \\ Togo \\ Uganda \\ Zambia
}




\section{Appendix IV: Technical Appendix for Chapter 4}

\section{A. Equations}

$\mathrm{X}^{1}=\mathrm{X}^{1}\left(\mathrm{~L}^{\mathrm{u}}, \mathrm{Z}\right)$

$\mathrm{X}^{2}=\mathrm{X}^{2}(\overline{\mathrm{e}} \mathrm{L}, \mathrm{s}, \mathrm{K})$

$E\left(p^{*}(1-t), 1, U^{A}\right)=p^{*}(1-t) X^{1}+X^{2}+t p^{*}\left(X^{1}-E_{1}\right)$

$\mathrm{v}\left(\mathrm{w}^{\mathrm{s}}\right)=\mathrm{v}\left(\mathrm{w}^{\mathrm{u}}\right)+\frac{\beta(\hat{\mathrm{e}})-\beta(\overline{\mathrm{e}})}{\pi}$

$\mathrm{w}=\mathrm{w}^{\mathrm{s}}\left(\overline{\mathrm{e}}, \mathrm{w}^{\mathrm{u}}\right)$

$p^{*}(1-t) \frac{\partial X^{1}}{\partial L^{u}}\left(L^{u}, Z\right)=w^{u}$

$\frac{\partial X^{2}}{\partial L^{s}}\left(\bar{e} L^{s}, K\right) \bar{e}=w s$

$\mathrm{L}^{\mathrm{u}}=\mathrm{L}^{\mathrm{u}}\left(\mathrm{p}^{*}, \mathrm{t}, \mathrm{w}^{\mathrm{u}}\right)$

$\mathrm{L}^{\mathrm{S}}=\mathrm{L}^{\mathrm{S}}\left(\overline{\mathrm{e}}, \mathrm{K}, \mathrm{w}^{\mathrm{S}}\right)$

$\mathrm{L}^{\mathrm{u}}\left(\mathrm{p}^{*}, \mathrm{t}, \mathrm{w}^{\mathrm{u}}\right)=\mathrm{L}^{-\mathrm{u}}+\overline{\mathrm{L}}^{-\mathrm{S}}-\mathrm{L}^{\mathrm{s}}\left(\mathrm{w}^{\mathrm{s}}\left(\overline{\mathrm{e}}, \mathrm{w}^{\mathrm{u}}\right)\right)$ 


$$
w^{\mathrm{u}}=\mathrm{w}^{\mathrm{u}}\left(\mathrm{p}^{*}, \mathrm{t}, \overline{\mathrm{e}}\right)
$$

\section{B. Comparative statics for trade liberalization and welfare}

Totally differentiating (3) gives:

$E_{u} d U+t p^{*} E_{1 u} d U=p^{*} d X^{1}+d X^{2}+t\left(p^{*}\right)^{2} E_{11} d t$

From (1) and (2):

$d X^{1}=\frac{\partial X^{1}}{\partial L^{u}} d L^{u}+\frac{\partial X^{1}}{\partial Z} d Z=\frac{w^{u}}{p^{*}(1-t)} d L^{u}$

$d X^{2}=\frac{\partial X^{2}}{\partial L^{s}} \bar{e} d L^{s}+\frac{\partial X^{2}}{\partial K} d K=w^{s} d L^{s}$

Dividing (10) by (9) and utilizing the result from (7) that $\mathrm{dL}^{\mathrm{u}}=-\mathrm{d}^{\mathrm{s}}$, we get:

$$
\frac{d X^{2}}{d X^{1}}=-\frac{p^{*}(1-t) w^{s}}{w^{u}}
$$

Using (11) in (8), we get: 


$$
\begin{aligned}
& E_{u} d U+t E^{*} E_{1 u} d U=p *\left(1-\frac{w^{s}+t w}{w^{u}}\right) d X^{1}+t\left(p^{*}\right)^{2} E_{11} d t \\
& \psi \frac{d U}{d t}=p^{*}\left(1-\frac{w^{s}+t w}{u}\right) \frac{d X}{w^{u}}+t\left(p^{*}\right)^{2} E_{11} \\
& \psi=E_{u}+t p^{*} E_{1 u}>0, E_{11}<0 \\
& \frac{w+t w}{w}=\frac{w}{w}(1+t)>1
\end{aligned}
$$

From (9):

$\frac{\mathrm{d} \mathrm{X}^{1}}{\mathrm{dt}}=\frac{\mathrm{w}^{\mathrm{u}}}{\mathrm{p}^{*}(1-\mathrm{t})} \frac{\mathrm{dL}^{\mathrm{u}}}{\mathrm{dt}}$

From (5a):

$$
\frac{d L^{u}}{d t}=\frac{\partial L^{u}}{\partial t}+\frac{\partial L^{u}}{\partial w} \frac{d w^{u}}{d t}
$$

Using the implicit function theorem on (5) we obtain (17) and (18): 


$$
\begin{aligned}
& \frac{\partial L^{\mathrm{u}}}{\partial \mathrm{t}}=\frac{\partial \mathrm{X}^{1} / \partial \mathrm{L}^{\mathrm{u}}}{(1-\mathrm{t}) \partial^{2} \mathrm{X}^{1} / \partial\left(\mathrm{L}^{\mathrm{u}}\right)^{2}}<0 \\
& \frac{\partial \mathrm{L}^{\mathrm{u}}}{\partial \mathrm{w}^{\mathrm{u}}}=\frac{1}{\mathrm{p}^{*}(1-\mathrm{t}) \partial^{2} \mathrm{X}^{1} / \partial\left(\mathrm{L}^{\mathrm{u}}\right)^{2}}<0
\end{aligned}
$$

From (7a):

$d w^{u}=\frac{\partial w^{u}}{\partial t} d t$

Therefore:

$\frac{\mathrm{d} \mathrm{w}^{\mathrm{u}}}{\mathrm{dt}}=\frac{\partial \mathrm{w}^{\mathrm{u}}}{\partial \mathrm{t}}$

Using the implicit function theorem on (7) we obtain

$$
\frac{\partial w^{u}}{\partial t}=-\frac{\frac{\partial L^{u}}{\partial t}}{\frac{\partial L^{u}}{\partial w^{u}}+\frac{\partial L^{s}}{\partial w} \frac{\partial w}{\partial w^{u}}}<0
$$

From (6): 
$\frac{\partial L^{S}}{\partial w}=\frac{1}{\partial^{2} X^{2} / \partial\left(L^{s}\right)^{2} \bar{e}^{2}}<0$

From (4):

$\frac{\partial \mathrm{w}^{\mathrm{s}}}{\partial \mathrm{w}^{\mathrm{u}}}=\frac{\mathrm{V}^{\prime}\left(\mathrm{w}^{\mathrm{u}}\right)}{\mathrm{V}^{\prime}\left(\mathrm{w}^{\mathrm{s}}\right)}>0$

Substituting (20) into (16) yields:

$\frac{d L^{\mathrm{u}}}{\mathrm{dt}}=\frac{\left(\partial \mathrm{L}^{\mathrm{u}} / \partial \mathrm{t}\right)\left(\partial \mathrm{L}^{\mathrm{s}} / \partial \mathrm{w}{ }^{\mathrm{s}}\right)\left(\partial \mathrm{w}^{\mathrm{s}} / \partial \mathrm{w}^{\mathrm{u}}\right)}{\partial \mathrm{L}^{\mathrm{u}} / \partial \mathrm{w}^{\mathrm{u}}+\left(\partial \mathrm{L}^{\mathrm{s}} / \partial \mathrm{w}^{\mathrm{s}}\right)\left(\partial \mathrm{w}^{\mathrm{s}} / \partial \mathrm{w}^{\mathrm{u}}\right)}<0$

Therefore $\frac{\mathrm{d} \mathrm{X}^{1}}{\mathrm{dt}}<0$, which implies that $\frac{\mathrm{dU}}{\mathrm{dt}}$ is ambiguous.

\section{Comparative statics for skilled labor demand}

Totally differentiating (6a) gives:

$d L^{S}=\frac{\partial L^{S}}{\partial \bar{e}} d \bar{e}+\frac{\partial L^{S}}{\partial K} d K+\frac{\partial L^{S}}{\partial w} d w$

Total differentiation of (4a) and (7a) gives: 
$d w^{s}=\frac{\partial w^{s}}{\partial \bar{e}} d \bar{e}+\frac{\partial w^{s}}{\partial w^{u}} d w^{u}$

$d w^{u}=\frac{\partial w^{u}}{\partial P} d P+\frac{\partial w^{u}}{\partial \bar{e}} d \bar{e}$

Substituting (24a) and (24b) into (24) yields:

$\mathrm{dL} \stackrel{\mathrm{s}}{=} \gamma \mathrm{de}+\frac{\partial \mathrm{L}^{\mathrm{S}}}{\partial \mathrm{K}} \mathrm{dK}+\delta \mathrm{dP}$

Where:

$\gamma=\frac{\partial \mathrm{L}^{\mathrm{s}}}{\partial \overline{\mathrm{e}}}+\frac{\partial \mathrm{L}^{\mathrm{s}}}{\partial \mathrm{w}}\left(\frac{\partial \mathrm{w}}{\partial \mathrm{w}} \frac{\partial \mathrm{w}^{\mathrm{u}}}{\partial \overline{\mathrm{e}}}+\frac{\partial \mathrm{w}^{\mathrm{s}}}{\partial \overline{\mathrm{e}}}\right)$

$\delta=\frac{\partial \mathrm{L}^{\mathrm{s}}}{\partial \mathrm{w}} \frac{\partial \mathrm{w}^{\mathrm{s}}}{\partial \mathrm{w}} \frac{\partial \mathrm{w}^{\mathrm{u}}}{\partial \mathrm{P}}<0$

$P=p^{*}(1-t)$

The effect of trade liberalization on skilled labor demand can be derived from (24c) and is given by:

$\frac{\mathrm{dL}^{\mathrm{s}}}{\mathrm{dt}}=-\delta \mathrm{p}^{*}$ 
Using the implicit function theorem on (5) and (7) yields:

$$
\begin{aligned}
& \frac{\partial \mathrm{L}^{\mathrm{u}}}{\partial \mathrm{P}}=-\frac{\phi(.)}{\mathrm{P} \partial \phi(.) / \partial \mathrm{L}^{\mathrm{U}}}>0 \\
& \phi(.)=\partial \mathrm{X}^{1} / \partial \mathrm{L}^{\mathrm{u}} \\
& \frac{\partial \mathrm{w}}{\partial \mathrm{P}}=-\left(\frac{\partial \mathrm{L}^{\mathrm{u}}}{\partial \mathrm{P}}\right) /\left(\frac{\partial \mathrm{L}^{\mathrm{u}}}{\partial \mathrm{w}^{\mathrm{U}}}+\frac{\partial \mathrm{L}^{\mathrm{s}}}{\partial \mathrm{w}} \frac{\partial \mathrm{w}^{\mathrm{s}}}{\partial \mathrm{w}^{\mathrm{u}}}\right)>0
\end{aligned}
$$

Therefore $\delta<0$, implying that $\frac{\mathrm{dL}^{\mathrm{S}}}{\mathrm{d} \mathrm{t}^{2}}>0$.

From (24c), the effect of effort on skilled labor demand is given by:

$$
\frac{\mathrm{dL}^{\mathrm{s}}}{\mathrm{de \overline {e }}}=\gamma
$$

Using the implicit function theorem on (4), (6) and (7) yields:

$$
\begin{aligned}
& \frac{\partial \mathrm{w}^{\mathrm{s}}}{\partial \overline{\mathrm{e}}}=-\left\{\beta^{\prime}(\overline{\mathrm{e}}) / \pi\right\} / \mathrm{v}^{\prime}\left(\mathrm{w}^{\mathrm{S}}\right)>0 \\
& \frac{\partial \mathrm{L}^{\mathrm{s}}}{\partial \overline{\mathrm{e}}}=-\left\{\Phi(.)+\overline{\mathrm{e}} \mathrm{L}^{\mathrm{S}} \partial \Phi(.) / \partial \overline{\mathrm{e}}\right\} /\left\{\partial \Phi(.) / \partial \mathrm{L}^{\mathrm{S}}\right\} \overline{\mathrm{e}}^{2}>0
\end{aligned}
$$




$$
\Phi(.)=\frac{\partial \mathrm{X}^{2}}{\partial \mathrm{L}^{\mathrm{S}}}(\overline{\mathrm{e}} \mathrm{L}, \mathrm{K})
$$

$$
\frac{\partial \mathrm{w}^{\mathrm{u}}}{\partial \overline{\mathrm{e}}}=-\left\{\frac{\partial \mathrm{L}^{\mathrm{s}}}{\partial \mathrm{w}} \frac{\partial \mathrm{w}^{\mathrm{s}}}{\partial \overline{\mathrm{e}}}\right\} /\left\{\frac{\partial \mathrm{L}^{\mathrm{u}}}{\partial \mathrm{w}^{\mathrm{U}}}+\frac{\partial \mathrm{L}^{\mathrm{s}}}{\partial \mathrm{w}} \frac{\partial \mathrm{w}^{\mathrm{s}}}{\partial \mathrm{w}^{\mathrm{u}}}\right\}<0
$$

Relations (27a) to (27d) imply that $\frac{\mathrm{dL}^{\mathrm{S}}}{\mathrm{de}}$ is ambiguous.

Finally the effect of $\mathrm{p}^{*}$ and $\mathrm{K}$ on $\mathrm{L}^{\mathrm{s}}$ can be obtained from (24c) as follows:

$$
\begin{aligned}
& \frac{\mathrm{dL}^{\mathrm{S}}}{\mathrm{dp}^{*}}=\delta(1-\mathrm{t})<0 \\
& \frac{\mathrm{dL}}{\mathrm{dK}}=\frac{\partial \mathrm{L}^{\mathrm{S}}}{\partial \mathrm{K}}
\end{aligned}
$$

Using the implicit function theorem on (6) yields:

$$
\frac{\partial \mathrm{L}^{\mathrm{S}}}{\partial \mathrm{K}}=-\{\partial \Phi(.) / \partial \mathrm{K}\} /\left\{\overline{\mathrm{e}} \partial \Phi(.) / \partial \mathrm{L}^{\mathrm{S}}\right\}>0
$$

Therefore $\frac{\mathrm{dL}^{\mathrm{s}}}{\mathrm{dK}}>0$. 